\title{
Synthesis and photo-physical properties of a series of BODIPY dyes
}

\author{
Stefano Banfi ${ }^{\mathrm{a}}$, Gianluca Nasini ${ }^{\mathrm{b}}$, Stefano Zaza ${ }^{\mathrm{c}}$, Enrico Caruso ${ }^{\mathrm{a}, *}$ \\ a Department of Theoretical and Applied Sciences (DiSTA), University of Insubria, Via J. H. Dunant 3, 21100 Varese, Italy \\ ${ }^{\mathrm{b}}$ Department of Chemistry, Materials and Chemical Engineering, Polytechnic of Milano, CNR-ICRM, Via Mancinelli 7, Milano, Italy \\ ' Shimadzu Italia srl Via G. B. Cassinis 7, 20139 Milano, Italy
}

\section{A R T I C L E I N F O}

\section{Article history:}

Received 23 October 2012

Received in revised form 3 April 2013

Accepted 15 April 2013

Available online 18 April 2013

\section{Keywords:}

BODIPY

Fluorescence

Singlet oxygen

Lipophilicity

$\mathrm{IC}_{50}$

Photodegradation

\begin{abstract}
A B S T R A C T
A series of 39 boron-dipyrrolylmethenes (BODIPYs) have been synthesized and characterized. Their spectroscopic properties, degree of lipophilicity, chemical stability under irradiation, and singlet-oxygen generation rate have also been studied. These compounds differ in the presence of ethyl groups (group A), hydrogens (group B) or iodines (group C) on the 2,6 positions; these appendices confer particular characteristics to each group. The presence of an aromatic substituent or hydrogen on the indacene 8 position produces 13 different molecules of each group. Besides the effects exerted by the group or atom on the 2,6 positions, the substituent on the 8 position exerts a further effect on the physico-chemical parameters, thus the desired properties of BODIPYs, concerning fluorescence, lipophilicity, and singlet oxygen production can be modulated accordingly.
\end{abstract}

(c) 2013 Elsevier Ltd. All rights reserved.

\section{Introduction}

After their introduction in $1968,{ }^{1}$ the 4,4 -difluoro-4-bora-3a,4adiaza-s-indacene chromophores (Fig. 1), also known as boron dipyrrolylmethenes but commonly named with the acronym BODIPY, have shown phenomenal growth in their applications and synthetic variants since the early nineties. ${ }^{2}$ Currently, BODIPY derivatives are employed in a wide range of applications, e.g., as tunable laser dyes, ${ }^{3}$ chemosensors, ${ }^{4}$ fluorescent switches, ${ }^{5}$ and biological labels. ${ }^{6}$ BODIPY dyes possess many distinctive and biologically favorable properties, such as high molar absorption coefficients, high fluorescent quantum yields, and long wavelengths of emission. ${ }^{7}$ Moreover, photochemical properties and chemical stabilities of the boron dipyrrolylmethene chromophore are higher than those of other dyes.

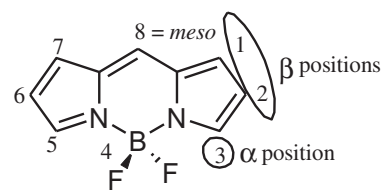

4,4-difluoro-4-bora-3a,4a-s-indacene

Fig. 1. Representation and numbering of a 4,4-difluoro-4-bora-3a,4a-diaza-s-indacene (BODIPY)

\footnotetext{
* Corresponding author. Tel.: +39 0332 421550; fax: +39 0332 421554; e-mail address: enrico.caruso@uninsubria.it (E. Caruso).
}

The absorption and emission characteristics of BODIPYs can be tuned by introducing appropriate substituents onto the BODIPY framework. The effect is particularly evident when the substituent is linked to a carbon atom of a pyrrole ring. ${ }^{8}$ On the contrary, the presence of an aromatic chemical group tethered on position 8 (meso) exerts a very weak effect, however it has been reported that the presence of a strong electron-withdrawing group, such as $\mathrm{CF}_{3}$, causes a deep bathochromic shift as compared to congeners with an aryl substituent on the same position. ${ }^{9}$

The weak effect of the aromatic ring is explained by the feeble electronic interaction between the aromatic ring and the BODIPY framework. In fact the two moieties are almost orthogonal to each other. ${ }^{10}$ Therefore, any structural difference on the meso-aryl group does not noticeably influence the intensity and wavelength of the absorption and fluorescence bands, however the degree of polarity of this moiety could modulate the lipophilic/hydrophilic balance of the molecule.

The presence of substituents on the 2,6 positions of the pyrrole units (both are $\beta$-pyrrole positions) exerts some evident effects; for instance the presence of alkyl groups or heavy atoms has a direct influence on the energy of the HOMO-LUMO orbitals, and on the population of the triplet state thus influencing the phenomena of absorption and emission of UV-vis radiation. ${ }^{11}$

Beside the well known fluorescence property that makes these molecules very useful as biomarkers, an important new field of application of BODIPYs concerns photodynamic therapy (PDT) as they can be used as photosensitizers once opportunely modified. ${ }^{12}$ PDT is an emerging modality for the eradication of some kind of 
small solid cancers. ${ }^{13}$ It is based on the intravenous or topical administration of a drug (a photosensitizer, PS) followed by irradiation, after a predetermined incubation period, with a visible light of an appropriate wavelength, which leads the formation of a PS in the excited state. The absorbed energy is then transferred to the neighboring molecules, especially to intracellular molecular oxygen, thus producing toxic oxygen radical species able to induce cell death. The basic factor influencing PDT outcome is the capability of the photosensitizer to produce singlet oxygen, the main cytotoxic agent involved in the killing of tumor cells in the PDT therapeutic process. ${ }^{14}$ The rate of singlet oxygen production of a PS is regulated by the efficiency of a spin-forbidden electronic transition, indicated as intersystem crossing (ISC), in which the electrons switch from the singlet to the triplet excited state. The introduction on the BODIPY frame of bulky and electron rich atoms, such as the large halogens $\mathrm{Br}$ and $\mathrm{I}$, is known to have an influence over the rates of ISC; this is named the heavy-atom effect. ${ }^{15}$ In fact, two different type of heavy-atom effect are recognized: the internal heavy-atom effect, in which heavy atoms are directly attached to the molecule, ${ }^{16}$ and the external heavy-atom effect, in which the photosensitizer is positioned in a heavy atom-containing environment, the first being much more effective than the second one. ${ }^{17}$

In this manuscript we report the synthesis of a wide series of BODIPY derivatives featuring alkyl, hydrogen or iodine substituents on the 2,6-pyrrolylmethene positions, thus forming three different groups of molecules. Thirty-six of these compounds bear an aromatic ring with variable structural characteristics on the meso position, whereas three compounds have an unsubstituted meso position featuring only a hydrogen atom. All of these molecules have been characterized and studied for their different physico-chemical properties, such as lipophilicity, absorption, and emission spectroscopies, chemical stability and, finally, the relative rate of singlet oxygen $\left({ }^{1} \mathrm{O}_{2}\right)$ generation. In particular the fluorescence quantum yields are measured in three solvents of different polarity, and the results discussed on the basis of the level of the HOMO energy of the aromatic moiety present on the 8 position of the BODIPY skeleton. Preliminary in vitro photodynamic studies, concerning the molecules characterized by the presence of iodine atoms on the dipyrrolylmethene frame, are also discussed in our text.

\section{Results and discussion}

\subsection{Synthesis}

The BODIPY derivatives were synthesized via acid catalyzed condensation of aromatic aldehydes and pyrroles following the general methods described by Akkaya and Liu. ${ }^{18}$ Two differently substituted pyrroles, the 2,4-dimethylpyrrole and the 3-ethyl-2,4dimethylpyrrole, were used in the condensation reactions with aromatic aldehydes, carried out in dichloromethane (DCM) or tetrahydrofuran (THF) in the presence of trifluoroacetic acid (TFA). The obtained dipyrrolylmethane intermediate was subsequently oxidized with 2,3-dichloro-5,6-dicyano-1,4-benzoquinone (DDQ) and then treated with $\mathrm{BF}_{3} \cdot \mathrm{Et}_{2} \mathrm{O}$ in the presence of $\mathrm{Et}_{3} \mathrm{~N}$, in the same reaction flask, yielding the desired pure BODIPY in fairly good yields after a single chromatographic separation.

Following this synthetic pathway (Scheme 1), we obtained BODIPYs characterized by the presence of ethyl appendices on the

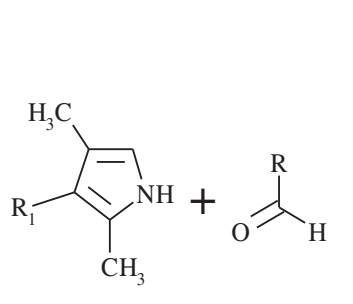

$\mathrm{R}_{1}=\mathrm{H}, \mathrm{Et}$

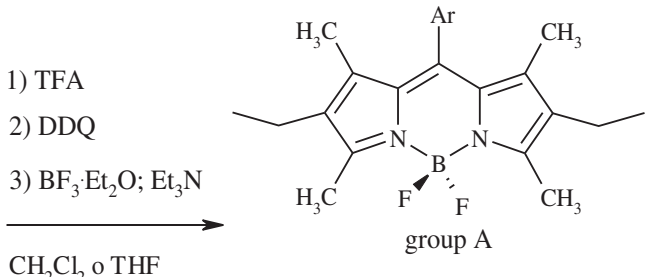

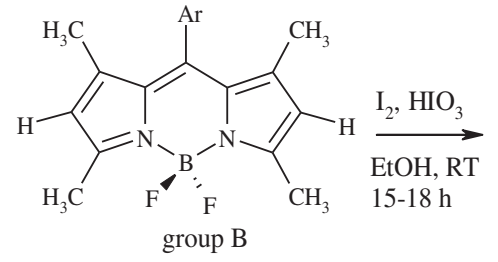<smiles></smiles>

group C<smiles>CCCCOc1c(I)cc(C)cc1OC</smiles><smiles>COc1ccc(C)cc1</smiles><smiles>COc1cccc(C)c1</smiles><smiles>Cc1ccc(O)cc1</smiles>

$\left[4,5-(\mathrm{MeO})_{2}, 3-\mathrm{I}\right]-\mathrm{Ph}$ 4-MeO-Ph<smiles>COc1ccccc1</smiles>
4-OH-Ph 4a-b*<smiles>Cc1c(F)c(F)c(F)c(F)c1F</smiles>

$$
\text { 4,7-(MeO) })_{2} \text {-Naphth }
$$$$
\text { 7a-c }
$$

2a-c<smiles>Cc1c(Cl)cccc1Cl</smiles>

$$
\begin{gathered}
2,6-\mathrm{Cl}_{2}-\mathrm{Ph} \\
\text { 8a-c }
\end{gathered}
$$<smiles>Cc1cccc(O)c1</smiles>

3-OH-Ph

5a-b*<smiles>Cc1ccncc1</smiles>

4-Py

11a-c<smiles>COc1ccc(C)c2ccccc12</smiles>

4-MeO-Naphth

6a-c

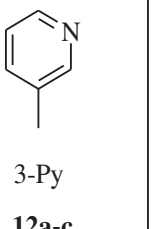

Scheme 1. Synthesis, structures, and acronyms of the BODIPY dyes ( ${ }^{*}$ for the structure of the per-iodinated compounds $\mathbf{4 c}$ and $\mathbf{5 c}$ see Fig. 3 ). 
2,6 positions of the dipyrrolylmethene (group A), and those bearing hydrogen atoms on the same positions (group B).

In this synthetic procedure, it is worth noticing that, in almost every acid catalyzed condensation between pyrrole and aromatic aldehyde, a low percentage (3-7\%) of the unsubstituted BODIPYs 13a,b may be isolated as a byproduct (Fig. 2). It seems that no correlation can be found between the nature of the aromatic moiety and the isolated yield of compounds $\mathbf{1 3 a}, \mathbf{b}$.

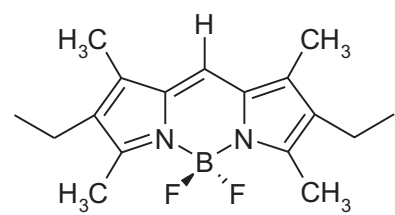

$13 a$

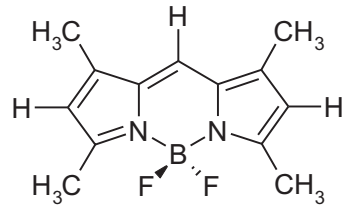

$13 b$
Fig. 2. Chemical structure of the byproducts $13 \mathbf{a}$ and $\mathbf{1 3 b}$

The BODIPYs characterized by hydrogen-bearing 2,6-positions $\left(\mathrm{R}^{1}=\mathrm{H}\right.$, Group $\left.\mathrm{B}\right)$ are modified by the insertion of two iodine atoms (Scheme 1) leading to the compounds of Group C. In the iodination process, we found that the conditions reported in the literature $\left(\mathrm{I}_{2}, \mathrm{HIO}_{3}, 60^{\circ} \mathrm{C}, 20 \mathrm{~min}\right)^{19}$ cause partial degradation of the boron-dipyrrolylmethenes skeleton, leading to extremely low yields of the desired compound. Lowering the temperature to $20-25{ }^{\circ} \mathrm{C}$ and increasing the reaction time to $15-18 \mathrm{~h}$ allows the recovery of the iodinated derivatives in fairly good yields $(>80 \%)$.

It must be considered that, in the presence of a phenolic group on the meso position of the BODIPY skeleton, iodination also occurs on the aromatic ring. This undesired reaction cannot be avoid as the hydroxyl substituent promotes electrophilic aromatic substitution, which occurs on the phenyl contemporaneously with the iodination of the 2,6 free positions. More specifically, two iodine atoms have been introduced on the $3^{\prime}, 5^{\prime}$ positions, when the aromatic ring was characterized by the presence of the hydroxyl group at the $4^{\prime}$ position (compound $4 \mathbf{c}$ ), whilst in the case of a phenyl bearing the hydroxyl on position $3^{\prime}$ the introduction of only one iodine atom at the $4^{\prime}$ position has been observed (compound 5c) (Fig. 3).

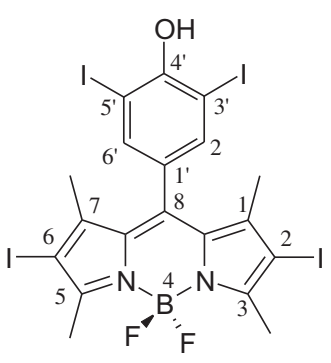

$4 c$

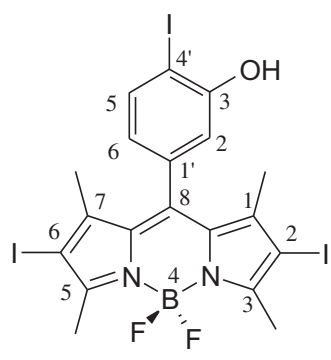

5 c
Fig. 3. Chemical structure of the two per-iodinated meso phenyl BODIPYs $\mathbf{4 c}$ and $\mathbf{5 c}$.

Compounds $10 a-c$ were synthesized from the corresponding compounds $\mathbf{9 a}-\mathbf{c}$ via nucleophilic aromatic substitution of the fluorine in position $4^{\prime}$ of the pentafluorophenyl group with 4methoxybenzylmercaptan. The reaction was carried out in THF, at reflux for $30 \mathrm{~min}$, in the presence of $\mathrm{K}_{2} \mathrm{CO}_{3}$ as base (Scheme 2).

In Tables 1-3 are reported the physico-chemical properties of the synthesized BODIPYs.

\subsection{Analytical data}

2.2.1. HPLC retention time. The lipophilicity of organic compounds is commonly evaluated measuring the molecule partition coefficient $(P)$ between 1-octanol and water. The values obtained following UV-vis analysis of both the organic and the aqueous phase are generally expressed as $\log P$; in this case values $>3$ indicate highly lipophilic molecules. This method cannot be applied when highly lipophilic (or, vice versa, hydrophilic) compounds are considered, as the absorbance of one or the other phase is too low to be spectrophotometrically detected. When spectroscopic methods cannot be applied, a relative scale of the lipophilicity of chemical compounds belonging to a homogeneous series can be determined measuring the HPLC retention time $\left(t_{R}\right)$. Performing the analyses on a reversed phase column (C18 is the most commonly used), under standardized conditions (eluant and flux), the most lipophilic compound will show the highest $t_{R}$. The average value of the $t_{R}\left(M_{t_{R}}\right)$ of each BODIPY group clearly indicates that the bulky and low polarity iodine atoms confer high lipophilicity to all the BODIPYs of the group C $\left(M_{t_{R}}\right)=13^{\prime} 54^{\prime \prime}$; the group A molecules, featuring the ethyl, show a $\left(M_{t_{\mathrm{R}}}\right)=9^{\prime} 10^{\prime \prime}$ while the $\mathrm{H}$ substituted BODIPYs (group B) are characterized by the shortest retention time with a $\left(M_{t_{\mathrm{R}}}\right)=7^{\prime} 08^{\prime \prime}$. These data indicate the possibility to modify the degree of lipophilicity of this class of molecules according to the nature of the group or atom placed on the 2,6 positions; as we will see later on (paragraph 2.2.4), the effect of having aromatic group in the meso position can further partially modify the hydrophilic/lipophilic nature of BODIPYs.

2.2.2. Absorption and fluorescence spectroscopy. Both the maximum-minimum values range and the average values of the extinction coefficients at $\lambda$ maximum indicate the highest absorbance of the hydrogen substituted compounds (group B) with a mean value of 84,300 , followed by those featuring the ethyl groups (group A, mean 76,300), while the presence of the iodine atoms further decreases the mean value of absorbance (group $C$, mean 73,000 ) although to a low extent. In every group, the absorbances in water (W) are lower than those registered in DCM, with the ratios $\mathrm{Abs}_{\mathrm{W}} / \mathrm{Abs}_{\mathrm{DCM}}$ ranging from 0.50 to 0.80 for most of the molecules. This occurrence is easily ascribable to the formation of aggregates of the lipophilic compounds in the aqueous medium. Indeed the largest decrease of absorbance is always associated with a broadening of the peak, as evidenced by the two or three times greater values of the full width at half maximum (FWHM) in water with respect to those in DCM. In particular, the BODIPYs of group B show the highest variability in the aqueous phase, indeed the highest value of FWHM is observed for the compound bearing a highly lipophilic naphthyl group ( $\mathbf{7 b}, F W H M=80)$ and the lowest for the more polar, hydroxy substituted, compounds $\mathbf{4 b}$ and $\mathbf{5 b}$ ( $F W H M=27$ and 28 , respectively).

As far as groups $A$ and $C$ are concerned the presence of the nonpolar and larger substituents on the 2,6 positions makes these compounds generally more lipophilic with respect to those of group B. It is conceivable that the meso-aryl group exerts a lower effect on the absorption band broadening in the water phase.

The $\lambda$ max values are instead well correlated to the presence of the particular substituents on the 2,6 positions of the dipyrrolylmethene skeleton, as the presence of ethyl groups causes a bathochromic shift of about $20 \mathrm{~nm}$, and the iodines produce a $30 \mathrm{~nm}$ shift with respect to the values recorded for the hydrogen bearing BODIPYs (group B). This latter shows $\lambda$ max range between 500 and $518 \mathrm{~nm}$, whereas the $\lambda$ max of compounds listed in groups $A$ and $C$ can be found in the range $524-536 \mathrm{~nm}$ and $532-548 \mathrm{~nm}$, respectively. The low difference about the observed position of the $\lambda$ max between the compound bearing two ethyls and those bearing two iodines (about $10 \mathrm{~nm}$ of difference) does not account for the 
<smiles>[R]C1=C(C)C2=C(c3c(F)c(F)c(F)c(F)c3F)c3c(C)c([R])c(C)n3B(F)[N+]2=C1C</smiles>

9a-c

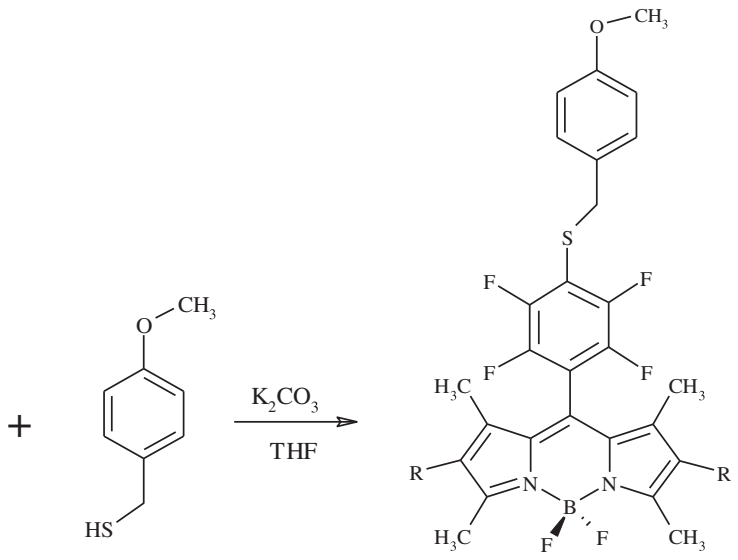

HS

$\mathrm{R}=\mathrm{Et}, \mathrm{H}, \mathrm{I}$

$(4-\mathrm{BzS})-\mathrm{F}_{4}-\mathrm{Ph}$

10a-c

Scheme 2. Nucleophilic aromatic substitution on pentafluorophenyl substituted BODIPYs 9a-c with 4-methoxybenzylmercaptan, affording compounds 10a-c.

Table 1

Physico-chemical properties of the compounds of group A (2,6-ethyl substituted BODIPYs)

\begin{tabular}{|c|c|c|c|c|c|c|c|}
\hline & 'meso' substituent & $\varepsilon($ DCM $) 524<\lambda<536$ & $\begin{array}{l}F W H M \\
(\mathrm{DCM})\end{array}$ & $\begin{array}{l}\varepsilon(\mathrm{W}) 520<\lambda<532 \\
(\varepsilon \text { Ratio W/DCM })\end{array}$ & $\begin{array}{l}F W H M(\mathrm{~W}) \\
\text { (Ratio W/DCM) }\end{array}$ & $\begin{array}{l}\operatorname{HPLC} t_{\mathrm{R}}-(\mathrm{RP} \mathrm{C} 18) \\
(\mathrm{min})\end{array}$ & ${ }^{1} \mathrm{O}_{2}{ }^{\mathrm{a}}$ \\
\hline 1a & {$\left[4,5-(\mathrm{MeO})_{2}, 3-\mathrm{I}\right]-\mathrm{Ph}$} & 92,600 & 27 & $75,100(0.81)$ & $57(2.1)$ & $10^{\prime} 27^{\prime \prime}$ & $4.92 \times 10^{-2}$ \\
\hline 2a & $4-\mathrm{MeO}-\mathrm{Ph}$ & 66,200 & 27 & $55,400(0.83)$ & $62(2.3)$ & $9^{\prime} 57^{\prime \prime}$ & $5.75 \times 10^{-2}$ \\
\hline $\mathbf{3 a}$ & 3-MeO-Ph & 84,300 & 27 & $60,100(0.73)$ & $62(2.3)$ & $9^{\prime} 50^{\prime \prime}$ & $6.81 \times 10^{-2}$ \\
\hline $4 a$ & $4-\mathrm{OH}-\mathrm{Ph}$ & 63,400 & 27 & $48,700(0.77)$ & $61(2.3)$ & $7^{\prime} 44^{\prime \prime}$ & $5.83 \times 10^{-2}$ \\
\hline $5 a$ & $3-\mathrm{OH}-\mathrm{Ph}$ & 72,000 & 27 & $58,900(0.82)$ & $62(2.3)$ & $8^{\prime} 00^{\prime \prime}$ & $6.81 \times 10^{-2}$ \\
\hline $6 \mathbf{a}$ & 4-MeO-Naphth & 80,500 & 23 & $61,500(0.76)$ & $62(2.7)$ & $12^{\prime} 12^{\prime \prime}$ & $6.69 \times 10^{-2}$ \\
\hline $7 \mathbf{a}$ & 4,7-(MeO $)_{2}-$ Naphth & 83,100 & 23 & $64,300(0.77)$ & $57(2.5)$ & $11^{\prime} 24^{\prime \prime}$ & $5.18 \times 10^{-2}$ \\
\hline $8 \mathbf{a}$ & $2,6-\mathrm{Cl}_{2}-\mathrm{Ph}$ & 72,100 & 28 & $41,000(0.57)$ & $65(2.3)$ & $4^{\prime} 17^{\prime \prime}$ & $1.17 \times 10^{-1}$ \\
\hline 9a & $\mathrm{F}_{5}-\mathrm{Ph}$ & 56,800 & 28 & $44,100(0.77)$ & $65(2.3)$ & $8^{\prime} 41^{\prime \prime}$ & $5.98 \times 10^{-2}$ \\
\hline $10 a$ & $(4-\mathrm{BzS})-\mathrm{F}_{4}-\mathrm{Ph}$ & 60,200 & 29 & $42,400(0.70)$ & $60(2.0)$ & $10^{\prime} 14^{\prime \prime}$ & $1.80 \times 10^{-1}$ \\
\hline 11a & 4-Py & 71,400 & 27 & $57,400(0.80)$ & $62(2.3)$ & $8^{\prime} 52^{\prime \prime}$ & $9.17 \times 10^{-2}$ \\
\hline $12 a$ & 3-Py & 57,000 & 29 & $53,800(0.94)$ & $65(2.2)$ & $8^{\prime} 27^{\prime \prime}$ & $1.06 \times 10^{-1}$ \\
\hline \multirow[t]{3}{*}{$13 a$} & $\mathrm{H}$ & 133,000 & 23 & $57,600(0.44)$ & $75(2.2)$ & $8^{\prime} 19^{\prime \prime}$ & $5.50 \times 10^{-2}$ \\
\hline & Range & $56.8 \div 133 \times 10^{3}$ & & $41 \div 75 \times 10^{3}$ & & $4^{\prime} 17^{\prime \prime} \div 12^{\prime} 12^{\prime \prime}$ & $4.92 \div 18 \times 10^{-2}$ \\
\hline & Mean & 76,300 & & 55,400 & & $9^{\prime} 10^{\prime \prime}$ & $7.92 \times 10^{-2}$ \\
\hline
\end{tabular}

a ${ }^{1} \mathrm{O}_{2}$ Comparative singlet-oxygen generation relative to Rose Bengal.

Table 2

Physico-chemical properties of the compounds of group B (2,6-hydrogen substituted BODIPYs)

\begin{tabular}{|c|c|c|c|c|c|c|c|}
\hline & 'meso' substituent & $\varepsilon(\mathrm{DCM}) 500<\lambda<518$ & $\begin{array}{l}\text { FWHM } \\
\text { (DCM) }\end{array}$ & $\begin{array}{l}\varepsilon(\mathrm{W}) 496<\lambda<510 \\
\text { (ratio } \mathrm{W} / \mathrm{DCM} \text { ) }\end{array}$ & $\begin{array}{l}F W H M(W) \\
\text { (Ratio W/DCM) }\end{array}$ & $\begin{array}{l}\operatorname{HPLC} t_{\mathrm{R}}-(\mathrm{RP} \text { C18) } \\
(\mathrm{min})\end{array}$ & ${ }^{1} \mathrm{O}_{2}{ }^{\mathrm{a}}$ \\
\hline 1b & {$\left[4,5-(\mathrm{MeO})_{2}, 3-\mathrm{I}\right]-\mathrm{Ph}$} & 109,800 & 19 & $74,900(0.68)$ & $52(2.7)$ & $7^{\prime} 48^{\prime \prime}$ & $1.17 \times 10^{-2}$ \\
\hline $2 \mathbf{b}$ & $4-\mathrm{MeO}-\mathrm{Ph}$ & 72,900 & 21 & $68,000(0.93)$ & $63(3.0)$ & $7^{\prime} 31^{\prime \prime}$ & $8.89 \times 10^{-3}$ \\
\hline 3b & 3-MeO-Ph & 62,200 & 20 & $48,600(0.79)$ & $57(2.8)$ & $7^{\prime} 28^{\prime \prime}$ & $8.91 \times 10^{-3}$ \\
\hline 4b & $4-\mathrm{OH}-\mathrm{Ph}$ & 65,200 & 21 & $63,400(0.96)$ & $28(1.3)$ & $6^{\prime} 22^{\prime \prime}$ & $8.13 \times 10^{-3}$ \\
\hline $\mathbf{5 b}$ & $3-\mathrm{OH}-\mathrm{Ph}$ & 79,800 & 21 & $79,000(0.99)$ & $27(1.3)$ & $6^{\prime} 29^{\prime \prime}$ & $1.90 \times 10^{-2}$ \\
\hline $6 b$ & 4-MeO-Naphth & 103,300 & 20 & $76,800(0.74)$ & $58(2.9)$ & $8^{\prime} 59^{\prime \prime}$ & $2.25 \times 10^{-2}$ \\
\hline 7b & $4,7-(\mathrm{MeO})_{2}-\mathrm{Naphth}$ & 94,300 & 19 & $61,000(0.64)$ & $80(4.2)$ & $8^{\prime} 16^{\prime \prime}$ & $4.95 \times 10^{-2}$ \\
\hline $\mathbf{8 b}$ & $2,6-\mathrm{Cl}_{2}-\mathrm{Ph}$ & 91,100 & 22 & $43,000(0.47)$ & $67(3.0)$ & $4^{\prime} 08^{\prime \prime}$ & $1.86 \times 10^{-2}$ \\
\hline $9 b$ & $\mathrm{~F}_{5}-\mathrm{Ph}$ & 61,500 & 22 & $49,700(0.81)$ & $66(3.0)$ & $6^{\prime} 48^{\prime \prime}$ & $4.28 \times 10^{-2}$ \\
\hline 10b & $(4-\mathrm{BzS})-\mathrm{F}_{4}-\mathrm{Ph}$ & 85,700 & 34 & $54,600(0.63)$ & $60(1.8)$ & $7^{\prime} 50^{\prime \prime}$ & $3.98 \times 10^{-2}$ \\
\hline 11b & $4-\mathrm{Py}$ & 85,700 & 28 & $60,100(0.69)$ & $71(2.5)$ & $6^{\prime} 53^{\prime \prime}$ & $9.96 \times 10^{-2}$ \\
\hline 12b & 3-Py & 69,800 & 29 & $46,800(0.67)$ & $61(2.1)$ & $6^{\prime} 40^{\prime \prime}$ & $1.68 \times 10^{-2}$ \\
\hline \multirow[t]{3}{*}{ 13b } & $\mathrm{H}$ & 115,000 & 17 & $71,100(0.62)$ & $68(4.0)$ & $6^{\prime} 31^{\prime \prime}$ & $1.64 \times 10^{-2}$ \\
\hline & Range & $61.5 \div 115 \times 10^{3}$ & & $43 \div 79 \times 10^{3}$ & & $4^{\prime} 08^{\prime \prime} \div 8^{\prime} 59^{\prime \prime}$ & $0.81 \div 9.96 \times 10^{-2}$ \\
\hline & Mean & 84,300 & & 61,300 & & $7^{\prime} 08^{\prime \prime}$ & $2.79 \times 10^{-2}$ \\
\hline
\end{tabular}

a ${ }^{1} \mathrm{O}_{2}$ Comparative singlet-oxygen generation relative to Rose Bengal.

different electronic effect of the two moieties, as the former exert only a weak positive inductive $(+\mathrm{I})$ effect while the latter has a weak electron-withdrawing effect $(-\mathrm{I})$ and a positive mesomeric $(+\mathrm{M})$ effect due to the electron pairs present on the iodine atoms, thus it seems that the bulkiness of the substituent is the main parameter affecting the $\lambda$ max.

The fluorescence data, reported in Table 3 for the 2,6-iodine substituted BODIPYs and in Table 4 for the other BODIPYs, have 
Table 3

Physico-chemical properties of the compounds of group C (2,6-iodine substituted BODIPYs)

\begin{tabular}{|c|c|c|c|c|c|c|c|c|}
\hline & 'meso' substituent & $\varepsilon(\mathrm{DCM}) 532<\lambda<548$ & $\begin{array}{l}\text { FWHM } \\
\text { (DCM) }\end{array}$ & $\begin{array}{l}\varepsilon(\mathrm{W}) 526<\lambda<540 \\
(\varepsilon \text { ratio } \mathrm{W} / \mathrm{DCM})\end{array}$ & $\begin{array}{l}\text { FWHM }(\mathrm{W}) \\
\text { (Ratio W/DCM) }\end{array}$ & $\begin{array}{l}\mathrm{HPLC} t_{\mathrm{R}}-(\mathrm{RP} C 18) \\
(\mathrm{min})\end{array}$ & $\begin{array}{l}\Phi_{\text {fluo }}{ }^{\mathrm{a}}(\lambda, \mathrm{nm}) \\
(\mathrm{DCM})\end{array}$ & ${ }^{1} \mathrm{O}_{2}{ }^{\mathrm{b}}$ \\
\hline 1c & {$\left[4,5-(\mathrm{MeO})_{2,3}, \mathrm{I}\right]-\mathrm{Ph}$} & 89,300 & 29 & $68,200(0.76)$ & $56(1.9)$ & $15^{\prime} 04^{\prime \prime}$ & $0.01(556)$ & 1.27 \\
\hline $2 c$ & $4-\mathrm{MeO}-\mathrm{Ph}$ & 61,500 & 30 & $35,000(0.57)$ & $77(2.6)$ & $14^{\prime} 42^{\prime \prime}$ & $0.02(551)$ & 1.04 \\
\hline $3 c$ & 3-MeO-Ph & 69,900 & 23 & $49,800(0.71)$ & $61(2.6)$ & $14^{\prime} 27^{\prime \prime}$ & $0.02(552)$ & 1.27 \\
\hline $4 c$ & $4-\mathrm{OH}-\mathrm{Ph}$ & 73,700 & 25 & $38,600(0.50)$ & $70(2.8)$ & $13^{\prime} 50^{\prime \prime}$ & $0.04(555)$ & 1.45 \\
\hline $5 c$ & $3-\mathrm{OH}-\mathrm{Ph}$ & 67,700 & 22 & $53,000(0.77)$ & $77(3.5)$ & $12^{\prime} 21^{\prime \prime}$ & $0.05(551)$ & 1.48 \\
\hline 6c & 4-MeO-Naphth & 72,000 & 28 & $51,000(0.70)$ & $58(2.1)$ & $20^{\prime} 44^{\prime \prime}$ & $0.02(555)$ & 1.27 \\
\hline 7c & $4,7-(\mathrm{MeO})_{2}-\mathrm{Naphth}$ & 97,800 & 28 & $73,200(0.74)$ & $58(2.1)$ & $17^{\prime} 32^{\prime \prime}$ & $0.01(556)$ & 1.33 \\
\hline $8 c$ & $2,6-\mathrm{Cl}_{2}-\mathrm{Ph}$ & 76,400 & 29 & $54,300(0.71)$ & $77(2.6)$ & $5^{\prime} 33^{\prime \prime}$ & $0.02(555)$ & 1.53 \\
\hline 9c & $\mathrm{F}_{5}-\mathrm{Ph}$ & 50,500 & 43 & $38,600(0.78)$ & $90(2.1)$ & $12^{\prime} 08^{\prime}$ & $0.01(578)$ & 1.20 \\
\hline $10 \mathrm{c}$ & $(4-B z S)-F_{4}-P h$ & 48,300 & 32 & $33,400(0.68)$ & $70(2.2)$ & $15^{\prime} 27^{\prime \prime}$ & $0.04(566)$ & 1.17 \\
\hline 11c & $4-\mathrm{Py}$ & 78,800 & 35 & $49,500(0.62)$ & $75(2.1)$ & $12^{\prime} 06^{\prime \prime}$ & $0.02(562)$ & 1.99 \\
\hline $12 c$ & 3-Py & 67,100 & 36 & $30,400(0.44)$ & $87(2.4)$ & $11^{\prime} 07^{\prime \prime}$ & $0.03(560)$ & 1.81 \\
\hline \multirow[t]{3}{*}{$13 c$} & $\mathrm{H}$ & 96,500 & 37 & $60,300(0.62)$ & $71(1.9)$ & $11^{\prime} 05^{\prime \prime}$ & $0.02(555)$ & 1.53 \\
\hline & Range & $97.8 \div 48.3 \times 10^{3}$ & & $30.4 \div 73.2 \times 10^{3}$ & & $5^{\prime} 33^{\prime \prime} \div 20^{\prime} 40^{\prime \prime}$ & $0.01 \div 0.05$ & $1.04 \div 1.99$ \\
\hline & Mean & 73,000 & & 48,900 & & $13^{\prime} 54^{\prime \prime}$ & $2.38 \times 10^{-2}$ & \\
\hline
\end{tabular}

a $\Phi$ represents quantum efficiency of fluorescence with fluorescein $(0.1 \mathrm{M} \mathrm{NaOH}, 0.85)$ as reference.

${ }^{b} \mathrm{O}_{2}$ Comparative singlet-oxygen generation relative to Rose Bengal.

Table 4

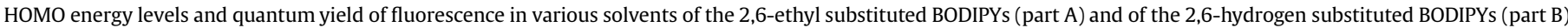

\begin{tabular}{|c|c|c|c|c|c|c|c|c|c|c|c|}
\hline \multicolumn{3}{|c|}{ HOMO energy $(\mathrm{eV})$} & \multirow{2}{*}{$\begin{array}{c}\text { Solvent } \\
\text { Hexane }\end{array}$} & \multirow{2}{*}{$\frac{\lambda_{\mathrm{em}}(\mathrm{nm})}{542}$} & \multirow{2}{*}{$\frac{\Phi_{\text {fluo }}}{0.38}$} & \multicolumn{3}{|c|}{ HOMO energy (eV) } & \multirow{2}{*}{$\frac{\text { Solvent }}{\text { Hexane }}$} & \multirow{2}{*}{$\frac{\lambda_{\mathrm{em}}(\mathrm{nm})}{551}$} & \multirow{2}{*}{$\frac{\Phi_{\text {fluo }}}{0.52}$} \\
\hline 1 & -8.8353 & $\mathbf{a}$ & & & & 8 & -9.4204 & $\mathbf{a}$ & & & \\
\hline & & & DCM & 544 & 0.45 & & & & DCM & 548 & 0.65 \\
\hline & & & $\mathrm{MeCN}$ & 542 & 0.27 & & & & $\mathrm{MeCN}$ & 548 & 0.49 \\
\hline & & b & Hexane & 519 & 0.37 & & & b & Hexane & 527 & 0.79 \\
\hline & & & DCM & 518 & 0.50 & & & & DCM & 526 & 0.88 \\
\hline & & & $\mathrm{MeCN}$ & 517 & 0.41 & & & & $\mathrm{MeCN}$ & 523 & 0.62 \\
\hline \multirow[t]{6}{*}{2} & -9.1150 & $\mathbf{a}$ & Hexane & 541 & 0.40 & 9 & -10.5472 & $\mathbf{a}$ & Hexane & 559 & 0.29 \\
\hline & & & DCM & 539 & 0.50 & & & & DCM & 561 & 0.34 \\
\hline & & & $\mathrm{MeCN}$ & 538 & 0.43 & & & & $\mathrm{MeCN}$ & 558 & 0.20 \\
\hline & & b & Hexane & 513 & 0.59 & & & b & Hexane & 528 & 0.68 \\
\hline & & & $\mathrm{DCM}$ & 513 & 0.74 & & & & $\mathrm{DCM}$ & 531 & 0.74 \\
\hline & & & $\mathrm{MeCN}$ & 511 & 0.31 & & & & $\mathrm{MeCN}$ & 530 & 0.60 \\
\hline \multirow[t]{6}{*}{3} & -9.1150 & $\mathbf{a}$ & Hexane & 540 & 0.37 & 10 & -9.2170 & $\mathbf{a}$ & Hexane & 558 & 0.42 \\
\hline & & & $\mathrm{DCM}$ & 541 & 0.48 & & & & DCM & 557 & 0.56 \\
\hline & & & $\mathrm{MeCN}$ & 538 & 0.34 & & & & $\mathrm{MeCN}$ & 557 & 0.38 \\
\hline & & b & Hexane & 512 & 0.51 & & & b & Hexane & 527 & 0.71 \\
\hline & & & $\mathrm{DCM}$ & 513 & 0.67 & & & & $\mathrm{DCM}$ & 533 & 0.81 \\
\hline & & & $\mathrm{MeCN}$ & 512 & 0.30 & & & & $\mathrm{MeCN}$ & 525 & 0.59 \\
\hline \multirow[t]{6}{*}{4} & -9.1745 & $\mathbf{a}$ & Hexane & 537 & 0.41 & 11 & -10.1047 & $\mathbf{a}$ & Hexane & 546 & 0.35 \\
\hline & & & DCM & 539 & 0.58 & & & & $\mathrm{DCM}$ & 541 & 0.50 \\
\hline & & & $\mathrm{MeCN}$ & 539 & 0.39 & & & & $\mathrm{MeCN}$ & 545 & 0.33 \\
\hline & & b & Hexane & 517 & 0.65 & & & b & Hexane & 520 & 0.66 \\
\hline & & & DCM & 513 & 0.70 & & & & $\mathrm{DCM}$ & 516 & 0.83 \\
\hline & & & $\mathrm{MeCN}$ & 513 & 0.57 & & & & $\mathrm{MeCN}$ & 518 & 0.53 \\
\hline \multirow[t]{6}{*}{5} & -9.1745 & $\mathbf{a}$ & Hexane & 540 & 0.47 & 12 & -10.1047 & $\mathbf{a}$ & Hexane & 542 & 0.40 \\
\hline & & & DCM & 540 & 0.50 & & & & DCM & 541 & 0.50 \\
\hline & & & $\mathrm{MeCN}$ & 538 & 0.32 & & & & $\mathrm{MeCN}$ & 542 & 0.42 \\
\hline & & b & Hexane & 515 & 0.49 & & & b & Hexane & 521 & 0.61 \\
\hline & & & DCM & 514 & 0.62 & & & & DCM & 514 & 0.62 \\
\hline & & & $\mathrm{MeCN}$ & 512 & 0.59 & & & & $\mathrm{MeCN}$ & 510 & 0.56 \\
\hline \multirow[t]{6}{*}{6} & -8.5161 & $\mathbf{a}$ & Hexane & 543 & 0.54 & 13 & & $\mathbf{a}$ & Hexane & 543 & 0.24 \\
\hline & & & DCM & 542 & 0.53 & & & & DCM & 544 & 0.34 \\
\hline & & & $\mathrm{MeCN}$ & 541 & 0.33 & & & & $\mathrm{MeCN}$ & 540 & 0.43 \\
\hline & & b & Hexane & 517 & 0.67 & & & b & Hexane & 514 & 0.87 \\
\hline & & & DCM & 517 & 0.70 & & & & DCM & 514 & 0.88 \\
\hline & & & $\mathrm{MeCN}$ & 515 & 0.12 & & & & $\mathrm{MeCN}$ & 510 & 0.76 \\
\hline \multirow[t]{6}{*}{7} & -8.4026 & $\mathbf{a}$ & Hexane & 542 & 0.39 & & & & & & \\
\hline & & & DCM & 543 & 0.44 & & & & & & \\
\hline & & & $\mathrm{MeCN}$ & 541 & 0.32 & & & & & & \\
\hline & & b & Hexane & 518 & 0.45 & & & & & & \\
\hline & & & DCM & 518 & 0.51 & & & & & & \\
\hline & & & $\mathrm{MeCN}$ & 517 & 0.009 & & & & & & \\
\hline
\end{tabular}

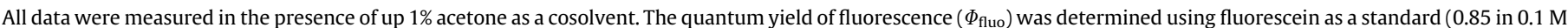

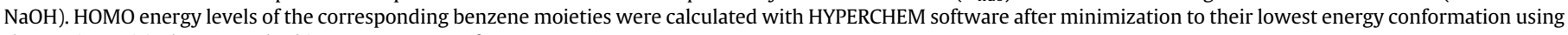
the semi-empirical PM3 method in HYPERCHEM software too. 
been normalized with respect to the value obtained using fluorescein as standard. ${ }^{20}$ It is known that the fluorescent properties of such dyes are controlled by electron transfer from the donor moiety (the aryl substituent in the meso position in our case) to the acceptor fluorophore (BODIPY core), therefore a peculiar dependence on solvent polarity could be observed. ${ }^{4 a, 21}$ Consequently we have measured the quantum yield of fluorescence of groups A and B in three different solvents, hexane, dichloromethane (DCM), and acetonitrile $(\mathrm{MeCN})$, characterized by particularly different dielectric constants, $1.89,9.14$, and 37.5, respectively. The BODIPYs included in group $\mathrm{C}$ were not considered in this study, as the iodine atoms exert a well known ISC effect, thus shifting the singlet excited state into the lower energetic triplet state causing a nearly complete inhibition of fluorescence to the advantage of a very high rate of singlet-oxygen generation.

The comparison of $\Phi_{\text {fluo }}$ obtained in the three solvents indicates that all compounds belonging to group B show a $\Phi_{\text {fluo }}>$ than those of group A and that in the whole set of compounds DCM allows a $\Phi_{\text {fluo }}$ higher than hexane and MeCN. Among these last two solvents the more polar acetonitrile inhibits the fluorescence to a greater extent with respect to hexane, however only when the aryl meso substituent had a higher HOMO energy level was an important inhibiting effect on fluorescence observed, as evidenced by the values obtained for compound $\mathbf{7 b}$ and, partially, for $\mathbf{6 b}$.

The inhibiting effect of polar solvents is absent in BODIPYs characterized by the presence of an aromatic ring in the meso position when its HOMO energy is very low, i.e., when electronwithdrawing groups are present on the aryl.

Compounds $\mathbf{8 a}$ and $\mathbf{8 b}$ show the highest $\Phi_{\text {fluo }}$ values in groups $\mathrm{A}$ and $B$, respectively. This can be explained by considering the presence of two chlorine atoms, bulky groups, on the ortho and ortho $^{\prime}$ positions of the 8-aryl substituted BODIPYs. In fact, it has been reported that the molecular rigidity arising from the introduction of bulky groups at the ortho positions minimizes the decrease in fluorescence intensity due to a nonradiative pathway. ${ }^{22}$

A particular case concerns compound $\mathbf{1 3 b}$ that shows the same high $\Phi_{\text {fluo }}$ value of $\mathbf{8 b}$, although it features the greatest number of hydrogen atoms in the indacene structure (positions 2, 6, and 8).

2.2.3. Singlet oxygen $\left({ }^{1} \mathrm{O}_{2}\right)$ production rate. For BODIPYs to be used as biological markers, ${ }^{6}$ their fluorescence should be at the possible utmost or, alternatively, if they have to act as photosensitizers then a high singlet oxygen production is required. Both processes take place after light absorption, and the structural differences in the BODIPY skeleton allow the different outcome of the energy loss from the excited state. In the first case the energy loss occurs from the singlet excited state through a strong light emission, possibly in the red visible region of light. On the contrary, when a massive production of singlet oxygen is required to impair the close biological structures, the triplet excited state must be involved from which the energy loss via light emission becomes a forbidden process; as a consequence this excited state can be lost with different pathways dissipating the energy to neighboring molecules. Among them, molecular oxygen is one of the favored targets, thus producing ${ }^{1} \mathrm{O}_{2}$, a short living but highly toxic compound when generated inside cells. The relative rates of singlet oxygen production are generally measured by comparing the results with a reference molecule; in this work Rose Bengal, a widely recognized singlet oxygen producer, was used as standard. ${ }^{23}$ The amount of ${ }^{1} \mathrm{O}_{2}$ produced by each photosensitizer was indirectly determined measuring the disappearance of the absorption band, at $410 \mathrm{~nm}$, of the 1,3-diphenylisobenzofuran (DPBF), a well known ${ }^{1} \mathrm{O}_{2}$ scavenger. $^{24}$ The experiments were carried out following a literature method, using isopropanol as solvent with a $50 \mu \mathrm{M}$ initial concentration of DPBF and in the presence of $2.5 \mu \mathrm{M}$ of BODIPY. Irradiation was obtained with a green LED device. The green light was chosen to ensure a good overlap between the $\lambda_{\max }$ of absorbance of these BODIPYs and the emission wavelength of the light, thus obtaining a maximum excitation power.

The values reported in Tables 1-3 show the great difference between the iodinated BODIPY of group $C$ and the other two groups. All the BODIPYs of group $C$ are largely more efficient than those belonging to groups $\mathrm{A}$ and $\mathrm{B}$ that indeed show a very poor ${ }^{1} \mathrm{O}_{2}$ outcome. It must be pointed out that the rate of singlet oxygen production, higher than the value obtained with Rose Bengal, measured for the BODIPYs belonging to the group $\mathrm{C}$, make these molecules particularly interesting for their application in photodynamic therapy. In particular an impressive rate of ${ }^{1} \mathrm{O}_{2}$ production is observed for the pyridyl bearing compounds 11c and 12c that show a 2-fold increased rate with respect to Rose Bengal.

The last comment concerns the influence of external iodine atoms on the efficacy of ${ }^{1} \mathrm{O}_{2}$ production rate; among the reported BODIPYs four of them feature one extra iodine atom on the meso phenyl $(\mathbf{1 a}-\mathbf{c}, \mathbf{5 c})$ and one molecule bears two iodine atoms $(\mathbf{4 c})$. In principle, an increased ${ }^{1} \mathrm{O}_{2}$ production rate might be expected, due to an external heavy-atom effect, however the values calculated for these compounds are slightly higher than the mean value of the corresponding group, thus indicating the absence of an external heavy-atom effect.

2.2.4. Effect of the substituent on position 8 (meso position) on the lipophilic/hydrophilic balance. The first observation is the comparable effect exerted by the meso substituent in each group, irrespective of the different substituent present in the 2,6 BODIPY positions. Besides the effect on absorbance, the aromatic group partially modifies the hydrophilicity of these molecules. Concerning the HPLC retention times, the aromatic moieties confer a higher lipophilicity to the BODIPYs as compared with the meso $\mathrm{H}$ substituted compounds. More precisely the molecules featuring the lipophilic naphthyl groups $(\mathbf{6 a}-\mathbf{c}, \mathbf{7 a}-\mathbf{c})$ show a greater affinity for the reversed phase HPLC column (C18), as witnessed by the highest $t_{\mathrm{R}}$ in each group. A similar effect was also found for compounds $\mathbf{1 0 a}-\mathbf{c}$, all characterized by the presence of a large and non-polar aromatic appendix. In the iodinated compounds of group $\mathrm{C}$, the presence of one or two more iodine atoms on the meso phenyl ring (compounds $\mathbf{4 c}$ and $\mathbf{5 c}$ ) does not seem to increase the lipophilicity, probably because the iodine in the 2,6 positions already confers a high hydrophobic character to these molecules. The presence of electron-withdrawing atoms or the presence of a hydroxyl group on the meso aromatic rings makes the BODIPY more polar, as shorter $t_{\mathrm{R}}$ were observed (compounds $4,5,9,11$, and 12 in every group). Particularly striking is the effect of the two chlorine atoms present in compounds $\mathbf{8 a}-\mathbf{c}$, conferring the highest hydrophilicity to these molecules, as witnessed by the low affinity for the stationary phase used. The $t_{R}$ of compounds $8 \mathbf{a}-\mathbf{c}$ are by far the shortest in each group and do not differ greatly with the nature of the group present on the 2,6 pyrrole positions.

The last aspect to be considered is the ${ }^{1} \mathrm{O}_{2}$ production that is remarkable for the BODIPYs of group $C$ only. In this group, the fluorescence is inhibited and the formation of the triplet excited state is favored by the presence of the iodine atoms on the 2,6 positions. An impressive rate of ${ }^{1} \mathrm{O}_{2}$ is observed for the pyridyl bearing compounds 11c and 12c, which show a 2-fold increased rate with respect to Rose Bengal, the reference compound known for its efficacy in singlet oxygen production. These last molecules should be considered in the application of BODIPYs in the field of PDT.

\subsection{Photodegradation of BODIPY dyes}

In in vivo PDT applications, the photodegradation of the photosensitizer plays an important role. Indeed, any PS with a high stability can turn out to be highly phototoxic for a prolonged time 
after the treatment, particularly when it is localized in the skin where sunlight can produce serious damage. On the other hand, a PS quickly decomposed by light can hardly be applied in therapy, as its efficacy could end before complete treatment of the diseased tissue. For this reason we have evaluated the stability of group $\mathrm{C}$ BODIPYs, those producing a good amount of ${ }^{1} \mathrm{O}_{2}$, and, for the sake of comparison, some analogues of the two other groups. Thus the stability of the series of compounds $\mathbf{5 a}-\mathbf{c}, \mathbf{7} \mathbf{a}-\mathbf{c}$, and $\mathbf{1 1 a}-\mathbf{c}$ were studied irradiating an aqueous $10 \mu \mathrm{M}$ solution of each BODIPY with the green LED and recording the absorbance every $15 \mathrm{~min}$. The results were plotted (Abs vs time) and the values of halfdegradation time evaluated with an exponential equation. As reported in Fig. 4 for a selected example with BODIPYs $\mathbf{7 a - c}$, it is evident that the degradation process rapidly occurs at high concentrations, whereas it slows down when the majority of the PS is already decomposed, thus indicating that a bimolecular process occurs under irradiation. It must be considered that the PS concentrations used in these analyses are much higher than those used in in vitro PDT experiments because of the necessity to start with the absorbance values at about $0.5-0.6$ for each compound. The average half-degradation time is $30 \mathrm{~min}$ for group A BODIPYs, and 50-60 min for the compounds of both group B and $C$, thus we decide to lengthen the time of irradiation to $120 \mathrm{~min}$, as the cell killing experiments rely on the presence, although it could be in low percentage, of intact PS up to the end of the irradiation period.

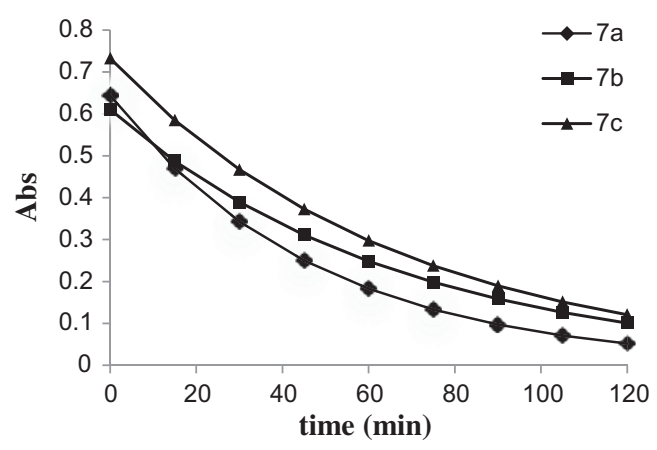

Fig. 4. Plot of photodegradation rate of the $\mathbf{7 a}-\mathbf{c}$ BODIPYs.

\subsection{In vitro preliminary evaluation of the photodynamic activity}

The BODIPYs of group $C$ were tested to study their phototoxic activity against ovarian carcinoma SKOV3 cells. For this purpose, cell cultures were treated with increasing concentrations of the BODIPYs. After $24 \mathrm{~h}$ of dark incubation, they were irradiated with a green LED device for $2 \mathrm{~h}$ (fluence $33 \mathrm{~J} / \mathrm{cm}^{2}$ ) and the efficacy of the treatment was determined with the MTT assay. The intrinsic effects of the PSs were assessed by omitting the irradiation step from the treatment protocol; it was found negligible in all cases up to $5 \mu \mathrm{M}$, thus indicating photoactivation to be an absolute requirement for the activity of these molecules. The 13 compounds of group $C$ were found to be particularly active ( $\mathrm{IC}_{50}$ values in the $\mathrm{nM}$ range), however the one featuring the hydrogen on the meso position was less active (13c, $\left.\mathrm{IC}_{50}=28.75 \mathrm{nM}\right)$ with respect to the meso-aryl derivatives $\left(0.65<\mathrm{IC}_{50}<8.03 \mathrm{nM}\right)$. From these results it is understood that the aromatic ring positioned in the 8 position of the dipyrrolylmethene skeleton exerts an important effect on the BODIPYs activity. In particular, compounds 8c and 2c showed interestingly high photodynamic efficiencies as the $\mathrm{IC}_{50}$ values were found 0.772 and $0.650 \mathrm{nM}$, respectively. To emphasize this, we are currently evaluating the relationship between chemical structure and photodynamic activity of these molecules with QSAR studies in order to plan the synthesis of new structure with, possibly, higher PDT efficacy.

\section{Conclusion}

The data presented in this work allows us to choose the reagents to synthesize BODIPYs suitable either for diagnostic purposes or for photodynamic therapy in which the fundamental features are determined by the presence of peculiar groups or atoms on the 2,6 positions. These characteristics can be further finely tuned by introducing aromatic rings with electron-withdrawing or electrondonating effects. In particular, the polarity of the BODIPY frame can be increased or diminished according to the groups hanging from the meso-aryl substituent, thus making these molecules more or less prone to cell penetration and, possibly, also with a particular internal distribution in the various cell organelles. We have recently demonstrated that a few of the molecules here reported have shown interesting photosensitizing capabilities against human colorectal carcinoma (HCT116) cells in in vitro assays. ${ }^{12}$ Furthermore compound 11c can be alkylated on the pyridyl nitrogen thus affording cationic BODIPYs, which have been found to be suitable for a photo induced killing effect against bacteria. ${ }^{25}$ The systematic study of these kind of molecules can bring further insight to the development of new photosensitizers suitable for both cancer cell killing or the eradication of localized infections.

\section{Experimental section}

\subsection{General}

IR spectra were measured on a Nicolet Avatar 360 FT-IR. ${ }^{1} \mathrm{H}$ NMR and ${ }^{13} \mathrm{C}$ NMR spectra were recorded on a Bruker $400 \mathrm{MHz}$ spectrometer in $\mathrm{CDCl}_{3}$ or DMSO- $d_{6}$; chemical shifts are expressed in parts per million relative to chloroform (7.28) and are reported as $s$ (singlet), d (doublet), t (triplet), m (multiplet), br s (broad singlet). Mass spectrometric measurements were performed on a Bruker Esquire 3000 Plus. Elemental analyses were performed on a ThermoQuest NA 2100, C, H, N analyzer, equipped with an electronic mass flow control and thermal conductivity detector. Merck $60 \mathrm{~F}_{254}$ silica gel precoated sheets $(0.2 \mathrm{~mm}$ thick) were used for analytical thin-layer chromatography (TLC). Silica gel 60 (70-230 mesh, Merck) was used for column chromatography. Aromatic aldehydes, 2,4-dimethyl-3-ethylpyrrole, and 2,4-dimethylpyrrole were commercial products (Sigma-Aldrich) and used as received. Dichloromethane used for BODIPY synthesis was distilled from $\mathrm{CaCl}_{2}$ directly into the reaction flask. HPLC analyses were conducted with an Agilent 1100 Series instrument coupled with a diode array detector. The instrument was fitted with a $250 \times 4.6 \mathrm{~mm}$ column (Supelco, Ascentis) packed with C-18 reversed-phase particles $(5 \mu \mathrm{m})$ and operated with an isocratic elution with $\mathrm{MeCN}$ at $0.5 \mathrm{~mL} /$ min. The green LED array is composed of $12 \times 3 \mathrm{~W}$ diodes $\left(\lambda_{\max }\right.$ of emission at $525 \mathrm{~nm}$, width at half maximum of $70 \mathrm{~nm}$ ), placed on an $11 \mathrm{~cm}$ diameter disk, and equipped with a heatsinker. The electric supply was ensured by a $50 \mathrm{~W}$ current transformer. This array was placed above the plate at such a distance as to produce a homogeneous irradiated area with a fluence rate (irradiance) of $1.31 \times 10^{-4} \mathrm{~W} / \mathrm{cm}^{2}$ at $525 \mathrm{~nm}$ ( $\lambda$ of maximum emission), as determined with an LI-COR 1800 spectroradiometer.

\subsection{Synthesis}

General comment on BODIPY synthesis. The acid catalyzed condensation step between pyrroles and aromatic aldehydes always produces the compound lacking the aromatic ring in variable yields ranging from 3 to $7 \%$. This arises from the loss of the aromatic moiety from the aldehyde carbon instead of the hydrogen in the oxidation process from dipyrrolylmethane to the corresponding methene. 
As an example, the reaction of 3-ethyl-2,4-dimethylpyrrole with 3-iodo-4,5-dimethoxybenzaldehyde gives 2,6-diethyl-1,3,5,7tetramethyl-8- $H-4,4^{\prime}$-difluoroboradiazaindacene (compound 13a) as byproduct of $\mathbf{1 a}$.

2,6-Diiodo-1,3,5,7-tetramethyl-8- $H$-4,4'-difluoroboradiazaindacene (13c), ${ }^{12 a}$ 2,6-diethyl-1,3,5,7-tetramethyl-8-(4-methoxyphenyl)-4,4'-difluoroboradiazaindacene (2a), ${ }^{12 b}$ 1,3,5,7-tetramethyl-8(4-methoxyphenyl)-4,4'-difluoroboradiazaindacene (2b), ${ }^{12 b} \quad 2,6$ diiodo-1,3,5,7-tetramethyl-8-(4-methoxyphenyl)-4,4'-difluoroboradiazaindacene (2c), ${ }^{12 \mathrm{~b}}$ 2,6-diethyl-1,3,5,7-tetramethyl-8-(4-hydroxyphenyl)-4,4'-difluoroboradiazaindacene $(\mathbf{4 a}),{ }^{12 b}$ 1,3,5,7-tetramethyl-8-(4-hydroxyphenyl)-4,4'-difluoroboradiazaindacene (4b), ${ }^{12 b}$ 2,6-diethyl-1,3,5,7-tetramethyl-8-(3-hydroxyphenyl)-4,4'-difluoroboradiazaindacene (5a), ${ }^{12 b}$ 1,3,5,7-tetramethyl-8-(3-hydroxyphenyl)$4,4^{\prime}$-difluoroboradiazaindacene (5b), ${ }^{12 \mathrm{~b}}$ 1,3,5,7-tetramethyl-8-(4-pyridyl)-4,4'-difluoroboradiazaindacene (11b), ${ }^{25} \quad$ 2,6-diiodo-1,3,5,7tetramethyl-8-(4-pyridyl)-4,4'-difluoroboradiazaindacene (11c), were synthesized as previously described.

4.2.1. 2,6-Diethyl-1,3,5,7-tetramethyl-8-(3-iodo-4,5-dimethoxyphenyl)-4,4'-difluoroboradiaza indacene (1a). 3-Iodo-4,5-dimethoxybenzaldehyde (1.5 mmol) and 2,4-dimethyl-3-ethylpyrrole ( $3.3 \mathrm{mmol}$ ) were dissolved in absolute $\mathrm{CH}_{2} \mathrm{Cl}_{2}(30 \mathrm{~mL})$ under $\mathrm{N}_{2}$ atmosphere, 10 drops of TFA were added and the solution was stirred at rt overnight or until TLC analysis showed complete consumption of the aldehyde. At this time of DDQ (2.5 mmol) were added and stirring continued for $20 \mathrm{~min}$. Then, $\mathrm{Et}_{3} \mathrm{~N}(4 \mathrm{~mL})$ and $\mathrm{BF}_{3} \cdot \mathrm{OEt}_{2}(4 \mathrm{~mL})$ were added. The mixture was stirred for $12 \mathrm{~h}$ then the organic layer containing the crude product was subsequently washed three times with water; the organic solution was dried over $\mathrm{Na}_{2} \mathrm{SO}_{4}$, and evaporated to dryness. The raw material was chromatographed $\left(\mathrm{SiO}_{2}\right.$, petroleum ether $\left./ \mathrm{CH}_{2} \mathrm{Cl}_{2}, 6: 4\right)$ affording $280 \mathrm{mg}$ (yield: $33 \%$ ) of $\mathbf{1 a}$ in the form of orange needles, $\mathrm{mp}$ $220{ }^{\circ} \mathrm{C}$. EA: calcd for $\mathrm{C}_{25} \mathrm{H}_{30} \mathrm{BF}_{2} \mathrm{IN}_{2} \mathrm{O}_{2}$ : C, 53.03; $\mathrm{H}, 5.34 ; \mathrm{N}, 4.95$; found: C, 53.47; $\mathrm{H}, 5.38 ; \mathrm{N}, 4.92 ; \mathrm{UV}-\mathrm{vis}_{\left(\mathrm{CH}_{2} \mathrm{Cl}_{2}\right)}$ : $528 \mathrm{~nm}$ $(\varepsilon=92,600)$; IR $\left(\mathrm{KBr}, \mathrm{cm}^{-1}\right) 2934(\mathrm{CH}), 2862(\mathrm{CH}), 1526,1172,988$, $524(\mathrm{CI}) ;{ }^{1} \mathrm{H} \mathrm{NMR}\left(\mathrm{CDCl}_{3}\right) \delta 1.00\left(\mathrm{t}, 6 \mathrm{H}, J=8 \mathrm{~Hz}, 2 \times \mathrm{CH}_{3}\right), 1.35(\mathrm{~s}, 6 \mathrm{H}$, $\left.2 \times \mathrm{CH}_{3}\right), 2.32\left(\mathrm{q}, 4 \mathrm{H}, \mathrm{J}=8 \mathrm{~Hz}, 2 \times \mathrm{CH}_{2}\right), 2.55\left(\mathrm{~s}, 6 \mathrm{H}, 2 \times \mathrm{CH}_{3}\right), 3.76(\mathrm{~s}$, $\left.3 \mathrm{H}, \mathrm{OCH}_{3}\right), 3.84\left(\mathrm{~s}, 3 \mathrm{H}, \mathrm{OCH}_{3}\right), 6.75$ (br s, $\left.1 \mathrm{H}\right), 7.25$ (br s, $\left.1 \mathrm{H}\right) ;{ }^{13} \mathrm{C}$ $\operatorname{NMR}\left(\mathrm{CDCl}_{3}\right) \delta 12.12,12.50,15.23,17.39,56.03,55.21,86.10,117.22$, 128.53, 133.88, 138.00, 139.21, 153.76, 154.35, 155.72; MS (ESI): $\mathrm{MNa}^{+}$, found: 588.98 calcd for $\mathrm{C}_{25} \mathrm{H}_{30} \mathrm{BF}_{2} \mathrm{IN}_{2} \mathrm{O}_{2}$ 566.23; HPLC: retention time $=10^{\prime} 27^{\prime \prime}(98.8 \%)$.

Compound 13a, mp $204{ }^{\circ} \mathrm{C}$; EA: calcd for $\mathrm{C}_{17} \mathrm{H}_{23} \mathrm{BF}_{2} \mathrm{~N}_{2}$ : C, 67.12; $\mathrm{H}, 7.62$; N, 9.21; found: C, 67.54; $\mathrm{H}, 7.65$; N, 9.30; $\mathrm{UV}-\mathrm{vis}_{\left(\mathrm{CH}_{2} \mathrm{Cl}_{2}\right)}$ : $526 \mathrm{~nm}(\varepsilon=133,000)$; IR ( $\left.\mathrm{KBr}, \mathrm{cm}^{-1}\right) 2956(\mathrm{CH}), 2924(\mathrm{CH}), 2839$ $(\mathrm{CH}), 1526,1172,988 ;{ }^{1} \mathrm{H} \mathrm{NMR}\left(\mathrm{CDCl}_{3}\right) \delta 1.00\left(\mathrm{t}, 6 \mathrm{H}, J=8 \mathrm{~Hz}, 2 \times \mathrm{CH}_{3}\right)$, $2.18\left(\mathrm{~s}, 6 \mathrm{H}, 2 \times \mathrm{CH}_{3}\right), 2.39\left(\mathrm{q}, 4 \mathrm{H}, J=8 \mathrm{~Hz}, 2 \times \mathrm{CH}_{2}\right), 2.54(\mathrm{~s}, 6 \mathrm{H}, 2 \times$ $\left.\mathrm{CH}_{3}\right), 6.96(\mathrm{~s}, 1 \mathrm{H}) ;{ }^{13} \mathrm{C}$ NMR $\left(\mathrm{CDCl}_{3}\right) \delta 12.02,12.61,14.88,16.99$, 131.29, 134.00, 137.13, 139.52, 153.21; MS (ESI): $\mathrm{MNa}^{+}$, found: 327.00 calcd for $\mathrm{C}_{17} \mathrm{H}_{23} \mathrm{BF}_{2} \mathrm{~N}_{2}$ 304.19; HPLC: retention time $=8^{\prime} 19^{\prime \prime}$ (99.58\%).

4.2.2. 1,3,5,7-Tetramethyl-8-(3-iodo-4,5-dimethoxyphenyl)-4,4'-difluoroboradiazaindacene (1b). 3-Iodo-4,5-dimethoxybenzaldehyde ( $1.5 \mathrm{mmol})$ and 2,4-dimethylpyrrole $(3.3 \mathrm{mmol})$ were reacted as described for compound 1a. The raw material was chromatographed $\left(\mathrm{SiO}_{2}\right.$, petroleum ether $\left./ \mathrm{CH}_{2} \mathrm{Cl}_{2}, 1: 1\right)$ affording $140 \mathrm{mg}$ (yield: $18 \%$ ) of $\mathbf{1 b}$ as orange needles, mp $218{ }^{\circ} \mathrm{C}$; EA: calcd for $\mathrm{C}_{21} \mathrm{H}_{22} \mathrm{BF}_{2} \mathrm{IN}_{2} \mathrm{O}_{2} \mathrm{C}, 49.44 ; \mathrm{H}, 4.35$; N, 5.49; found: C, 49.08; $\mathrm{H}, 4.36$; $\mathrm{N}, 5.53 ; \mathrm{UV}-\mathrm{vis}_{\left(\mathrm{CH}_{2} \mathrm{Cl}_{2}\right)}: 504 \mathrm{~nm}(\varepsilon=109,800) ; \mathrm{IR}\left(\mathrm{KBr}, \mathrm{cm}^{-1}\right) 2946$ $(\mathrm{CH}), 2854(\mathrm{CH}), 1534,1184,990,524(\mathrm{CI}) ;{ }^{1} \mathrm{H}$ NMR $\left(\mathrm{CDCl}_{3}\right) \delta 1.43(\mathrm{~s}$, $\left.6 \mathrm{H}, 2 \times \mathrm{CH}_{3}\right), 2.48\left(\mathrm{~s}, 6 \mathrm{H}, 2 \times \mathrm{CH}_{3}\right), 3.76\left(\mathrm{~s}, 3 \mathrm{H}, \mathrm{OCH}_{3}\right), 3.83(\mathrm{~s}, 3 \mathrm{H}$, $\left.\mathrm{OCH}_{3}\right), 5.92(\mathrm{~s}, 2 \mathrm{H}), 6.75(\mathrm{~d}, J=3 \mathrm{~Hz}, 1 \mathrm{H}), 7.23(\mathrm{~d}, J=3 \mathrm{~Hz}, 1 \mathrm{H}) ;{ }^{13} \mathrm{C}$ $\operatorname{NMR}\left(\mathrm{CDCl}_{3}\right) \delta 14.78,56.03,55.38,87.29,116.32,130.22,135.22$, 138.10, 138.98, 153.26, 154.61, 155.29; $\mathrm{MS}$ (ESI): $\mathrm{MNa}^{+}$, found:
533.01 calcd for $\mathrm{C}_{21} \mathrm{H}_{22} \mathrm{BF}_{2} \mathrm{IN}_{2} \mathrm{O}_{2}$ 510.12; HPLC: retention time$=7^{\prime} 48^{\prime \prime}(99.8 \%)$.

Compound 13b, mp $214{ }^{\circ} \mathrm{C}$; EA: calcd for $\mathrm{C}_{13} \mathrm{H}_{15} \mathrm{BF}_{2} \mathrm{~N}_{2}$ : C, 62.94; $\mathrm{H}, 6.09 ; \mathrm{N}, 11.29$; found: C, 63.02; $\mathrm{H}, 6.10 ; \mathrm{N}, 11.33 ; \mathrm{UV}-\mathrm{vis}_{\left(\mathrm{CH}_{2} \mathrm{Cl}_{2}\right)}$ : $506 \mathrm{~nm}(\varepsilon=115,000)$; IR $\left(\mathrm{KBr}, \mathrm{cm}^{-1}\right) 2968(\mathrm{CH}), 2920(\mathrm{CH}), 2865$ $(\mathrm{CH}), 1529,1184,974 ;{ }^{1} \mathrm{H}$ NMR $\left(\mathrm{CDCl}_{3}\right) \delta 2.17\left(\mathrm{~s}, 6 \mathrm{H}, 2 \times \mathrm{CH}_{3}\right), 2.47(\mathrm{~s}$, $\left.6 \mathrm{H}, 2 \times \mathrm{CH}_{3}\right), 5.96(\mathrm{~s}, 1 \mathrm{H}), 6.95(\mathrm{~s}, 2 \mathrm{H}) ;{ }^{13} \mathrm{C} \mathrm{NMR}\left(\mathrm{CDCl}_{3}\right) \delta 14.65$, 127.29, 134.01, 137.63, 139.78, 154.01; MS (ESI): $\mathrm{MNa}^{+}$found: 270.96 calcd for $\mathrm{C}_{13} \mathrm{H}_{15} \mathrm{BF}_{2} \mathrm{~N}_{2}$ 248.08; HPLC: retention time $=6^{\prime} 31^{\prime \prime}(100 \%)$.

4.2.3. 2,6-Diiodo-1,3,5,7-tetramethyl-8-(3-iodo-4,5-dimethoxyphenyl)-4,4'-difluoroboradiaza indacene (1c). Compound 1b $(0.069 \mathrm{mmol}), \mathrm{I}_{2}(0.138 \mathrm{mmol})$, and $\mathrm{HIO}_{3}(0.138 \mathrm{mmol})$ were dissolved in EtOH $(5 \mathrm{~mL})$. This mixture was stirred for $15-18 \mathrm{~h}$ at rt. The solution was then washed with water and extracted three times with $\mathrm{CH}_{2} \mathrm{Cl}_{2}$, the organic phase was dried over $\mathrm{Na}_{2} \mathrm{SO}_{4}$, and evaporated to dryness. The crude product was purified by column chromatography $\left(\mathrm{SiO}_{2}\right.$, petroleum ether $/ \mathrm{CH}_{2} \mathrm{Cl}_{2}, 1: 1$ ) affording $28 \mathrm{mg}$ (yield: $53 \%$ ) of $\mathbf{1 c}$ as red needles, $\mathrm{mp}>300^{\circ} \mathrm{C}$; EA: calcd for $\mathrm{C}_{21} \mathrm{H}_{20} \mathrm{BF}_{2} \mathrm{I}_{3} \mathrm{~N}_{2} \mathrm{O}_{2} \mathrm{C}, 33.10 ; \mathrm{H}, 2.65 ; \mathrm{N}, 3.68$; found: $\mathrm{C}, 33.21 ; \mathrm{H}, 2.67$; N, 3.66; UV - vis ${\left(\mathrm{CH}_{2} \mathrm{Cl}_{2}\right)}$ : $538 \mathrm{~nm}(\varepsilon=89,300)$; IR $\left(\mathrm{KBr}, \mathrm{cm}^{-1}\right) 2922$ (CH), $2851(\mathrm{CH}), 1530,1174,994,524(\mathrm{CI}) ;{ }^{1} \mathrm{H}$ NMR $\left(\mathrm{CDCl}_{3}\right) \delta 1.48(\mathrm{~s}$, $\left.6 \mathrm{H}, 2 \times \mathrm{CH}_{3}\right), 2.58\left(\mathrm{~s}, 6 \mathrm{H}, 2 \times \mathrm{CH}_{3}\right), 3.76\left(\mathrm{~s}, 3 \mathrm{H}, \mathrm{OCH}_{3}\right), 3.84(\mathrm{~s}, 3 \mathrm{H}$, $\left.\mathrm{OCH}_{3}\right), 6.70(\mathrm{~d}, J=2 \mathrm{~Hz}, 1 \mathrm{H}), 7.21(\mathrm{~d}, J=2 \mathrm{~Hz}, 1 \mathrm{H}) ;{ }^{13} \mathrm{C} \mathrm{NMR}\left(\mathrm{CDCl}_{3}\right)$ $\delta$ 15.09, 56.09, 55.42, 87.69, 88.14, 115.97, 135.38, 138.10, 138.68, 153.15, 154.48, 155.66; MS (ESI): $\mathrm{M}-1^{+}$found: 760.74 calcd for $\mathrm{C}_{21} \mathrm{H}_{20} \mathrm{BF}_{2} \mathrm{I}_{3} \mathrm{~N}_{2} \mathrm{O}_{2}$ 761.92; HPLC: retention time $=15^{\prime} 04^{\prime \prime}$ (99.6\%).

4.2.4. 2,6-Diethyl-1,3,5,7-tetramethyl-8-(3-methoxyphenyl)-4,4'-difluoroboradiazaindacene (3a). 2,4-Dimethyl-3-ethylpyrrole (3.3 $\mathrm{mmol}$ ) and 3-methoxybenzaldehyde $(1.5 \mathrm{mmol})$ were made to react as described for compound 1a. The raw material was purified by column chromatography $\left(\mathrm{SiO}_{2}\right.$, petroleum ether $\left.\mathrm{CH}_{2} \mathrm{Cl}_{2}, 6: 4\right)$ affording $236 \mathrm{mg}$ (yield: 38\%) of 3a as orange needles, $\mathrm{mp} 184{ }^{\circ} \mathrm{C}$; EA: calcd for $\mathrm{C}_{24} \mathrm{H}_{29} \mathrm{BF}_{2} \mathrm{~N}_{2} \mathrm{O} \mathrm{C}, 70.25 ; \mathrm{H}, 7.12 ; \mathrm{N}, 6.83$; found: $\mathrm{C}, 70.48$; $\mathrm{H}, 7.13 ; \mathrm{N}, 6.81 ; \mathrm{UV}-\operatorname{vis}_{\left(\mathrm{CH}_{2} \mathrm{Cl}_{2}\right)}: 524 \mathrm{~nm}(\varepsilon=84,300) ; \mathrm{IR}\left(\mathrm{KBr}, \mathrm{cm}^{-1}\right)$ $2976(\mathrm{CH}), 2922(\mathrm{CH}), 2854(\mathrm{CH}), 1528,1179,992,754 ;{ }^{1} \mathrm{H}$ NMR $\left(\mathrm{CDCl}_{3}\right) \delta 1.01\left(\mathrm{t}, 6 \mathrm{H}, J=7.5 \mathrm{~Hz}, 2 \times \mathrm{CH}_{3}\right), 1.37\left(\mathrm{~s}, 6 \mathrm{H}, 2 \times \mathrm{CH}_{3}\right), 2.33(\mathrm{q}$, $\left.4 \mathrm{H}, J=7.5 \mathrm{~Hz}, 2 \times \mathrm{CH}_{2}\right), 2.55\left(\mathrm{~s}, 6 \mathrm{H}, 2 \times \mathrm{CH}_{3}\right), 3.84\left(\mathrm{~s}, 3 \mathrm{H}, \mathrm{OCH}_{3}\right), 6.85$ $(\mathrm{m}, 1 \mathrm{H}), 6.89(\mathrm{~d}, J=8 \mathrm{~Hz}, 1 \mathrm{H}), 7.02(\mathrm{dd}, J=8,3 \mathrm{~Hz}, 1 \mathrm{H}), 7.41(\mathrm{t}, J=8 \mathrm{~Hz}$, $1 \mathrm{H}) ;{ }^{13} \mathrm{C} \mathrm{NMR}\left(\mathrm{CDCl}_{3}\right) \delta 12.13,12.74,15.18,17.25,56.04,116.19,128.01$, $128.59,131.43,133.02,138.59,139.69,152.99,155.15$; MS (ESI): $\mathrm{M}-1^{+}$ found: 409.11 calcd for $\mathrm{C}_{24} \mathrm{H}_{29} \mathrm{BF}_{2} \mathrm{~N}_{2} \mathrm{O}$ 410.31; HPLC: retention time $=9^{\prime} 50^{\prime \prime}(98.4 \%)$.

4.2.5. 1,3,5,7-Tetramethyl-8-(3-methoxyphenyl)-4,4'-difluoroboradiazaindacene (3b). 3-Methoxybenzaldehyde $(1.5 \mathrm{mmol})$ and 2,4dimethylpyrrole $(3.3 \mathrm{mmol})$ were made to react as described for compound 1a. The raw material was purified by column chromatography $\left(\mathrm{SiO}_{2}\right.$, petroleum ether $\left.-\mathrm{CH}_{2} \mathrm{Cl}_{2}, 1: 1\right)$ affording $131 \mathrm{mg}$ (yield: $25 \%$ ) of $\mathbf{3 b}$ as orange needles, mp $180{ }^{\circ} \mathrm{C}$; EA: calcd for $\mathrm{C}_{20} \mathrm{H}_{21} \mathrm{BF}_{2} \mathrm{~N}_{2} \mathrm{O}$ C, 67.82; H, 5.98; N, 7.91; found: C, 67.99; H, 6.00; N, 7.91; UV - vis $\left(\mathrm{CH}_{2} \mathrm{Cl}_{2}\right)$ : $500 \mathrm{~nm}(\varepsilon=62,200)$; IR $\left(\mathrm{KBr}, \mathrm{cm}^{-1}\right) 2928$ $(\mathrm{CH}), 2841(\mathrm{CH}), 1526,1183,998,752 ;{ }^{1} \mathrm{H} \mathrm{NMR}\left(\mathrm{CDCl}_{3}\right) \delta 1.47(\mathrm{~s}, 6 \mathrm{H}$, $\left.2 \times \mathrm{CH}_{3}\right), 2.57\left(\mathrm{~s}, 6 \mathrm{H}, 2 \times \mathrm{CH}_{3}\right), 3.84\left(\mathrm{~s}, 3 \mathrm{H}, \mathrm{OCH}_{3}\right), 6.00(\mathrm{~s}, 2 \mathrm{H}), 6.85$ (br s, $1 \mathrm{H}), 6.89(\mathrm{~d}, J=8 \mathrm{~Hz}, 1 \mathrm{H}), 7.02(\mathrm{dd}, J=8,2 \mathrm{~Hz}, 1 \mathrm{H}), 7.41(\mathrm{t}$, $J=8 \mathrm{~Hz}, 1 \mathrm{H}) ;{ }^{13} \mathrm{C}$ NMR $\left(\mathrm{CDCl}_{3}\right) \delta 14.79,55.55,114.75,121.08,121.36$, $127.85,129.48,141.81,143.39,155.66,158.64$; $\mathrm{MS}$ (ESI): $\mathrm{M}-1^{+}$ found: 353.28 calcd for $\mathrm{C}_{20} \mathrm{H}_{21} \mathrm{BF}_{2} \mathrm{~N}_{2} \mathrm{O}$ 354.20; HPLC: retention time $=7^{\prime} 28^{\prime \prime}(97.2 \%)$.

4.2.6. 2,6-Diiodo-1,3,5,7-tetramethyl-8-(3-methoxyphenyl)-4,4'-difluoroboradiazaindacene (3c). Compound $3 \mathbf{b}(0.127 \mathrm{mmol}), \mathrm{I}_{2}$ $(0.254 \mathrm{mmol})$, and $\mathrm{HIO}_{3}(0.254 \mathrm{mmol})$ were made to react as described for compound 1c. The crude product was purified by column chromatography $\left(\mathrm{SiO}_{2}\right.$, petroleum ether $\left.-\mathrm{CH}_{2} \mathrm{Cl}_{2}, 1: 1\right)$ 
affording $33 \mathrm{mg}$ (yield: $43 \%$ ) of $3 \mathrm{c}$ as red needles, $\mathrm{mp} 209{ }^{\circ} \mathrm{C}$; EA: calcd for $\mathrm{C}_{20} \mathrm{H}_{19} \mathrm{BF}_{2} \mathrm{I}_{2} \mathrm{~N}_{2} \mathrm{O} \mathrm{C}$, 39.64; $\mathrm{H}, 3.16 ; \mathrm{N}, 4.62$; found: $\mathrm{C}, 40.01$; $\mathrm{H}, 3.18$; N, 4.65; UV - vis $\left(\mathrm{CH}_{2} \mathrm{Cl}_{2}\right): 534 \mathrm{~nm}(\varepsilon=61,500) ; \mathrm{IR}\left(\mathrm{KBr}, \mathrm{cm}^{-1}\right)$ $2922(\mathrm{CH}), 2850(\mathrm{CH}), 1533,1177,991,753 ; 524(\mathrm{CI}) ;{ }^{1} \mathrm{H}$ NMR $\left(\mathrm{CDCl}_{3}\right) \delta 1.38\left(\mathrm{~s}, 6 \mathrm{H}, 2 \times \mathrm{CH}_{3}\right), 2.57\left(\mathrm{~s}, 6 \mathrm{H}, 2 \times \mathrm{CH}_{3}\right), 3.74(\mathrm{~s}, 3 \mathrm{H}$, $\left.\mathrm{OCH}_{3}\right), 6.71(\mathrm{~m}, 1 \mathrm{H}), 6.76(\mathrm{~d}, J=4 \mathrm{~Hz}, 1 \mathrm{H}), 6.97(\mathrm{dd}, J=8,2 \mathrm{~Hz}, 1 \mathrm{H})$, $7.35(\mathrm{t}, J=8 \mathrm{~Hz}, 1 \mathrm{H}) ;{ }^{13} \mathrm{C} \mathrm{NMR}\left(\mathrm{CDCl}_{3}\right) \delta 15.23,55.67,86.35,115.01$, $122.12,122.39,127.36,141.02,143.25,155.99,158.72$; MS (ESI): $\mathrm{M}-1^{-}$found: 604.86 calcd for $\mathrm{C}_{20} \mathrm{H}_{19} \mathrm{BF}_{2} \mathrm{I}_{2} \mathrm{~N}_{2} \mathrm{O}$ 605.99; HPLC: retention time $=14^{\prime} 27^{\prime \prime}(99.1 \%)$.

4.2.7. 2,6-Diiodo-1,3,5,7-tetramethyl-8-(4-hydroxy-3,5-diiodophenyl)$4,4^{\prime}$-difluoroboradiaza indacene (4c). Compound $\mathbf{4 b}(0.088 \mathrm{mmol}), \mathrm{I}_{2}$ $(0.166 \mathrm{mmol})$, and $\mathrm{HIO}_{3}(0.166 \mathrm{mmol})$ were made to react as described for compound 1c. The crude product was purified by column chromatography $\left(\mathrm{SiO}_{2}\right.$, petroleum ether $\left.-\mathrm{CH}_{2} \mathrm{Cl}_{2}, 4: 6\right)$ affording $45 \mathrm{mg}$ (yield: $61 \%$ ) of $\mathbf{4 c}$ as red needles, $\mathrm{mp}>300{ }^{\circ} \mathrm{C}$; EA: calcd for $\mathrm{C}_{19} \mathrm{H}_{15} \mathrm{BF}_{2} \mathrm{I}_{4} \mathrm{~N}_{2} \mathrm{O}$ C, 27.05; $\mathrm{H}, 1.79$; N, 3.32; found: $\mathrm{C}, 26.93 ; \mathrm{H}, 1.78 \%$; 3.30; UV - vis ${\left(\mathrm{CH}_{2} \mathrm{Cl}_{2}\right)}$ : $532 \mathrm{~nm}(\varepsilon=73,700) ; \mathrm{IR}\left(\mathrm{KBr}, \mathrm{cm}^{-1}\right) 3450(\mathrm{OH})$, $2922(\mathrm{CH}), 1535,1305,1172,993,524(\mathrm{CI}) ;{ }^{1} \mathrm{H}$ NMR $\left(\mathrm{CDCl}_{3}\right) \delta 1.54(\mathrm{~s}$, $\left.6 \mathrm{H}, 2 \times \mathrm{CH}_{3}\right), 2.63\left(\mathrm{~s}, 6 \mathrm{H}, 2 \times \mathrm{CH}_{3}\right), 7.61(\mathrm{~s}, 2 \mathrm{H}) ;{ }^{13} \mathrm{C} \mathrm{NMR}\left(\mathrm{CDCl}_{3}\right)$ $\delta$ 15.02, 81.66, 85.02, 121.33, 127.31, 129.66, 141.99, 142.88, 155.71, 156.32; MS (ESI): $\mathrm{M}-1^{-}$found: 842.52 calcd for $\mathrm{C}_{19} \mathrm{H}_{15} \mathrm{BF}_{2} \mathrm{I}_{4} \mathrm{~N}_{2} \mathrm{O}$ 843.76; HPLC: retention time $=13^{\prime} 50^{\prime \prime}(100.0 \%)$.

4.2.8. 2,6-Diiodo-1,3,5,7-tetramethyl-8-(3-hydroxy-4-iodophenyl)$4,4^{\prime}$-difluoroboradiaza indacene $(\mathbf{5 c})$. Compound $\mathbf{5 b}(0.088 \mathrm{mmol})$, $\mathrm{I}_{2}(0.166 \mathrm{mmol})$, and $\mathrm{HIO}_{3}(0.166 \mathrm{mmol})$ were made to react as described for compound 1c. The crude product was purified by column chromatography $\left(\mathrm{SiO}_{2}\right.$, petroleum ether $\left.-\mathrm{CH}_{2} \mathrm{Cl}_{2}, 6: 4\right)$ affording $40 \mathrm{mg}$ (yield: $63 \%$ ) of $\mathbf{5 c}$ as red needles, $\mathrm{mp}>300{ }^{\circ} \mathrm{C}$; EA: calcd for $\mathrm{C}_{19} \mathrm{H}_{16} \mathrm{BF}_{2} \mathrm{I}_{3} \mathrm{~N}_{2} \mathrm{O} \mathrm{C}, 31.79 ; \mathrm{H}, 2.25 ; \mathrm{N}, 3.90$; found: $\mathrm{C}, 32.00$; $\mathrm{H}, 2.27$; N, 3.92; UV - vis $\left(\mathrm{CH}_{2} \mathrm{Cl}_{2}\right): 536 \mathrm{~nm}(\varepsilon=67,700)$; IR $(\mathrm{KBr}$, $\left.\mathrm{cm}^{-1}\right) 3481(\mathrm{OH}), 2961(\mathrm{CH}), 2927(\mathrm{CH}), 2869(\mathrm{CH}), 1538,1474,1190$, 977, $526(\mathrm{CI}) ;{ }^{1} \mathrm{H}$ NMR $\left(\mathrm{CDCl}_{3}\right) \delta 1.42\left(\mathrm{~s}, 6 \mathrm{H}, 2 \times \mathrm{CH}_{3}\right), 2.56(\mathrm{~s}, 6 \mathrm{H}, 2 \times$ $\left.\mathrm{CH}_{3}\right), 5.54(\mathrm{~s}, 1 \mathrm{H}, \mathrm{OH}), 6.52(\mathrm{dd}, J=8,2 \mathrm{~Hz}, 1 \mathrm{H}), 6.82(\mathrm{~d}, J=2 \mathrm{~Hz}, 1 \mathrm{H})$; $7.74(\mathrm{~d}, J=8 \mathrm{~Hz}, 1 \mathrm{H}) ;{ }^{13} \mathrm{C} \mathrm{NMR}\left(\mathrm{CDCl}_{3}\right) \delta 14.78,81.98,85.74,115.33$, 124.78, 130.96, 136.35, 139.77, 143.09, 153.71, 156.32; MS (ESI): $\mathrm{M}-1^{-}$found: 716.67 calcd for $\mathrm{C}_{19} \mathrm{H}_{16} \mathrm{BF}_{2} \mathrm{I}_{3} \mathrm{~N}_{2} \mathrm{O}$ 717.86; HPLC: retention time $=12^{\prime} 21^{\prime \prime}(97.2 \%)$.

4.2.9. 2,6-Diethyl-1,3,5,7-tetramethyl-8-(4-methoxynaphthalene)4,4'-difluoroboradiaza indacene (6a). 4-Methoxy-1-naphthaldehyde (1.5 $\mathrm{mmol})$ and 2,4-dimethyl-3-ethylpyrrole (3.3 $\mathrm{mmol})$ were made to react as described for compound 1a. After stirring for $12 \mathrm{~h}$, the organic layer containing the crude product was washed with a solution of $\mathrm{HCl}(10 \%)$, two times with water and one time with $\mathrm{NaCl}$ saturated solution (Brine); the organic solution was dried over $\mathrm{Na}_{2} \mathrm{SO}_{4}$ and evaporated to dryness. The raw material was chromatographed on silica gel (petroleum ether $-\mathrm{CH}_{2} \mathrm{Cl}_{2}, 6: 4$ ) affording $280 \mathrm{mg}$ (yield: $41 \%$ ) of $\mathbf{6 a}$ as orange needles, mp $241^{\circ} \mathrm{C}$; EA: calcd for $\mathrm{C}_{28} \mathrm{H}_{31} \mathrm{BF}_{2} \mathrm{~N}_{2} \mathrm{O} \mathrm{C}, 73.05 ; \mathrm{H}, 6.79 ; \mathrm{N}, 6.09$; found: $\mathrm{C}$, 72.88; H, 6.80; N, 6.10; UV - vis ${ }_{\left(\mathrm{CH}_{2} \mathrm{Cl}_{2}\right)}$ : $528 \mathrm{~nm}(\varepsilon=80,500)$; IR $\left(\mathrm{KBr}, \mathrm{cm}^{-1}\right) 2964(\mathrm{CH}), 2854(\mathrm{CH}), 1538,1502,1189,977 ;{ }^{1} \mathrm{H}$ NMR $\left(\mathrm{CDCl}_{3}\right) \delta 0.87\left(\mathrm{t}, 6 \mathrm{H}, J=8 \mathrm{~Hz}, 2 \times \mathrm{CH}_{3}\right), 0.93\left(\mathrm{~s}, 6 \mathrm{H}, 2 \times \mathrm{CH}_{3}\right), 2.18(\mathrm{q}$, $\left.4 \mathrm{H}, J=8 \mathrm{~Hz}, 2 \times \mathrm{CH}_{2}\right), 2.48\left(\mathrm{~s}, 6 \mathrm{H}, 2 \times \mathrm{CH}_{3}\right), 4.01\left(\mathrm{~s}, 3 \mathrm{H}, \mathrm{OCH}_{3}\right), 6.82(\mathrm{~d}$, $J=9 \mathrm{~Hz}, 1 \mathrm{H}), 7.19(\mathrm{t}, J=9 \mathrm{~Hz}, 1 \mathrm{H}), 7.35(\mathrm{t}, J=9,2 \mathrm{~Hz}, 1 \mathrm{H}), 7.41(\mathrm{t}, J=9$, $2 \mathrm{~Hz}, 1 \mathrm{H}), 7.62(\mathrm{~d}, J=9 \mathrm{~Hz}, 1 \mathrm{H}), 8.23(\mathrm{~d}, J=9 \mathrm{~Hz}, 1 \mathrm{H}) ;{ }^{13} \mathrm{C} \mathrm{NMR}\left(\mathrm{CDCl}_{3}\right)$ $\delta$ 11.56, 13.01, 14.96, 16.85, 55.70, 101.93, 103.76, 116.21, 117.88, $120.52,124.29,124.02,127.66,131.32,132.47,134.45,138.79,139.22$, 153.63, 156.09; MS (ESI): $M-1^{-}$found: 459.20 calcd for $\mathrm{C}_{28} \mathrm{H}_{31} \mathrm{BF}_{2} \mathrm{~N}_{2} \mathrm{O}$ 460.37; HPLC: retention time $=12^{\prime} 12^{\prime \prime}$ (93.5\%).

4.2.10. 1,3,5,7-Tetramethyl-8-(4-methoxynaphthalene)-4,4'-difluoroboradiazaindacene $(\boldsymbol{6 b})$. 4-Methoxy-1-naphthaldehyde (1.5 mmol) and 2,4-dimethylpyrrole $(3.3 \mathrm{mmol})$ were made to react as described for compound 1a. At the end of the reaction the organic layer was treated as above. The raw material was chromatographed on silica gel (petroleum ether- $\mathrm{CH}_{2} \mathrm{Cl}_{2}, 1: 1$ ) affording $270 \mathrm{mg}$ (yield: $41 \%$ ) of $\mathbf{6 b}$ as orange needles, mp $252{ }^{\circ} \mathrm{C}$; EA: calcd for $\mathrm{C}_{24} \mathrm{H}_{23} \mathrm{BF}_{2} \mathrm{~N}_{2} \mathrm{O}$ C, 71.30; $\mathrm{H}, 5.73 ; \mathrm{N}, 6.93$; found: C, 70.97; $\mathrm{H}, 5.68 ; \mathrm{N}$, 6.89; UV - vis $\left.\mathrm{CH}_{2} \mathrm{Cl}_{2}\right): 504 \mathrm{~nm}(\varepsilon=103,300) ; \mathrm{IR}\left(\mathrm{KBr}, \mathrm{cm}^{-1}\right) 2956$ (CH), $2852(\mathrm{CH}), 1537,1506,1187,1153,977 ;{ }^{1} \mathrm{H}$ NMR $\left(\mathrm{CDCl}_{3}\right) \delta 1.11$ $\left(\mathrm{s}, 6 \mathrm{H}, 2 \times \mathrm{CH}_{3}\right), 2.59\left(\mathrm{~s}, 6 \mathrm{H}, 2 \times \mathrm{CH}_{3}\right), 4.07\left(\mathrm{~s}, 3 \mathrm{H}, \mathrm{OCH}_{3}\right), 5.91(\mathrm{~s}, 2 \mathrm{H})$, $6.90(\mathrm{~d}, J=9 \mathrm{~Hz}, 1 \mathrm{H}), 7.25(\mathrm{~d}, J=9 \mathrm{~Hz}, 1 \mathrm{H}), 7.42(\mathrm{td}, J=9,2 \mathrm{~Hz}, 1 \mathrm{H}), 7.49$ $(\mathrm{td}, J=9,2 \mathrm{~Hz}, 1 \mathrm{H}), 7.70(\mathrm{~d}, J=9 \mathrm{~Hz}, 1 \mathrm{H}), 8.31(\mathrm{~d}, J=9 \mathrm{~Hz}, 1 \mathrm{H}) ;{ }^{13} \mathrm{C} \mathrm{NMR}$ $\left(\mathrm{CDCl}_{3}\right) \delta 11.61,13.11,55.82,102.32,103.57,116.39,117.91,120.36$, 124.41, 124.27, 127.61, 128.32, 132.56, 134.51, 138.66, 138.94, 153.68, 155.98; MS (ESI): $\mathrm{M}-1^{+}$found: 403.17 calcd for $\mathrm{C}_{24} \mathrm{H}_{23} \mathrm{BF}_{2} \mathrm{~N}_{2} \mathrm{O}$ 404.26; HPLC: retention time $=8^{\prime} 59^{\prime \prime}(94.0 \%)$.

4.2.11. 2,6-Diiodo-1,3,5,7-tetramethyl-8-(4-methoxynaphthalene)$4,4^{\prime}$-difluoroboradiaza indacene $(\mathbf{6 c})$. Compound $\mathbf{6 b}(0.074 \mathrm{mmol})$, $\mathrm{I}_{2}(0.148 \mathrm{mmol})$, and $\mathrm{HIO}_{3}(0.148 \mathrm{mmol})$ were made to react as described for compound 1c. The crude product was recovered by filtration then crystallized out of $\mathrm{MeOH}$ affording $30 \mathrm{mg}$ (yield: $62 \%$ ) of $6 \mathrm{c}$ as red needles, $\mathrm{mp}>300^{\circ} \mathrm{C}$; EA: $\mathrm{C}, 43.94 ; \mathrm{H}, 3.23$; $\mathrm{N}, 4.27$; found: C, 43.90; $\mathrm{H}, 3.22 ; \mathrm{N}, 4.28 ; \mathrm{UV}-\mathrm{vis}_{\left(\mathrm{CH}_{2} \mathrm{Cl}_{2}\right)}$ : $538 \mathrm{~nm}$ $(\varepsilon=72,000)$; IR $\left(\mathrm{KBr}, \mathrm{cm}^{-1}\right) 2956(\mathrm{CH}), 2852(\mathrm{CH}), 1529,1305,1172$, 994; 769, $524(\mathrm{CI}) ;{ }^{1} \mathrm{H}$ NMR $\left(\mathrm{CDCl}_{3}\right) \delta 1.07\left(\mathrm{~s}, 6 \mathrm{H}, 2 \times \mathrm{CH}_{3}\right), 2.60(\mathrm{~s}$, $\left.6 \mathrm{H}, 2 \times \mathrm{CH}_{3}\right), 4.01\left(\mathrm{~s}, 3 \mathrm{H}, \mathrm{OCH}_{3}\right), 6.83(\mathrm{~d}, J=8 \mathrm{~Hz}, 1 \mathrm{H}), 7.17(\mathrm{~d}, J=8 \mathrm{~Hz}$, $1 \mathrm{H}), 7.38(\mathrm{td}, J=8,1 \mathrm{~Hz}, 1 \mathrm{H}), 7.42(\mathrm{td}, J=8,1 \mathrm{~Hz}, 1 \mathrm{H}), 7.55(\mathrm{~d}, J=8 \mathrm{~Hz}$, $1 \mathrm{H}), 8.27(\mathrm{~d}, J=8 \mathrm{~Hz}, 1 \mathrm{H}) ;{ }^{13} \mathrm{C}$ NMR $\left(\mathrm{CDCl}_{3}\right) \delta 11.79,14.16,55.61$, 84.98, 103.14, 104.01, 116.32, 117.80, 121.21, 124.56, 124.95, 127.32, 132.11, 134.63, 138.79, 138.38, 153.57, 155.26; MS (ESI): $\mathrm{M}-1^{+}$ found: 654.93 calcd for $\mathrm{C}_{24} \mathrm{H}_{21} \mathrm{BF}_{2} \mathrm{I}_{2} \mathrm{~N}_{2} \mathrm{O}$ 656.05; HPLC: retention time $=20^{\prime} 44^{\prime \prime}(99.7 \%)$.

4.2.12. 2,6-Diethyl-1,3,5,7-tetramethyl-8-(4,7-dimethoxynaphthalene)-4,4'-difluoroboradiaza indacene (7a). 4,7-Dimethoxy-1naphthaldehyde (1.5 $\mathrm{mmol})$ and 2,4-dimethyl-3-ethylpyrrole (3.3 mmol) were made to react as described for compound 1a. At the end of the reaction the organic layer was treated as above. The raw material was chromatographed $\left(\mathrm{SiO}_{2}\right.$, petroleum ether $-\mathrm{CH}_{2} \mathrm{Cl}_{2}, 7: 3$ ) affording $124 \mathrm{mg}$ (yield: $17 \%$ ) of $7 \mathbf{a}$ as orange needles, mp $280{ }^{\circ} \mathrm{C}$; EA: calcd for $\mathrm{C}_{29} \mathrm{H}_{33} \mathrm{BF}_{2} \mathrm{~N}_{2} \mathrm{O}_{2} \mathrm{C}, 71.03 ; \mathrm{H}, 6.78$; $\mathrm{N}, 5.71$; found: $\mathrm{C} 71.37 ; \mathrm{H}, 6.83, \mathrm{~N}, 5.73$; $\mathrm{UV}-\mathrm{vis}_{\left(\mathrm{CH}_{2} \mathrm{Cl}_{2}\right)}$ : $528 \mathrm{~nm}$ $(\varepsilon=83,100)$; IR $\left(\mathrm{KBr}, \mathrm{cm}^{-1}\right) 2962(\mathrm{CH}), 2926(\mathrm{CH}), 2869(\mathrm{CH}), 1536$, 1316, 1187, 976; ${ }^{1} \mathrm{H}$ NMR $\left(\mathrm{CDCl}_{3}\right) \delta 0.87\left(\mathrm{t}, 6 \mathrm{H}, J=8 \mathrm{~Hz}, 2 \times \mathrm{CH}_{3}\right), 1.02$ (s, $6 \mathrm{H}, 2 \times \mathrm{CH}_{3}$ ), 2.19 (q, $\left.4 \mathrm{H}, J=8 \mathrm{~Hz}, 2 \times \mathrm{CH}_{2}\right), 2.50\left(\mathrm{~s}, 6 \mathrm{H}, 2 \times \mathrm{CH}_{3}\right)$, $3.66\left(\mathrm{~s}, 3 \mathrm{H}, \mathrm{OCH}_{3}\right), 3.98\left(\mathrm{~s}, 3 \mathrm{H}, \mathrm{OCH}_{3}\right), 6.70(\mathrm{~d}, J=8 \mathrm{~Hz}, 1 \mathrm{H}), 6.91(\mathrm{~d}$, $J=3 \mathrm{~Hz}, 1 \mathrm{H}), 7.06$ (dd, $J=9,3 \mathrm{~Hz}, 1 \mathrm{H}), 7.13(\mathrm{~d}, J=8 \mathrm{~Hz}, 1 \mathrm{H}), 8.15(\mathrm{~d}$, $J=9 \mathrm{~Hz}, 1 \mathrm{H}) ;{ }^{13} \mathrm{C} \mathrm{NMR}\left(\mathrm{CDCl}_{3}\right) \delta 11.41,12.70,14.79,17.18,55.68$, 55.71, 102.21, 103.88, 117.71, 120.88, 124.08, 124.40, 127.35, 131.85, 132.62, 134.54, 138.46, 139.17, 153.64, 156.41, 159.16; MS (ESI): $\mathrm{MNa}^{+}$found: 513.12 calcd for $\mathrm{C}_{29} \mathrm{H}_{33} \mathrm{BF}_{2} \mathrm{~N}_{2} \mathrm{O}_{2}$ 490.39; HPLC: retention time $=11^{\prime} 24^{\prime \prime}(98.6 \%)$.

4.2.13. 1,3,5,7-Tetramethyl-8-(4,7-dimethoxynaphthalene)-4,4'-difluoroboradiazaindacene (7b). 4,7-Dimethoxy-1-naphthaldehyde (1.5 $\mathrm{mmol})$ and 2,4-dimethyl-3-ethylpyrrole $(3.3 \mathrm{mmol})$ were made to react as described for compound 1a. At the end of the reaction the organic layer was treated as above. The raw material was purified by column chromatography $\left(\mathrm{SiO}_{2}\right.$, petroleum ether/ $\mathrm{CH}_{2} \mathrm{Cl}_{2}, 4: 6$ ) affording $124 \mathrm{mg}$ (yield: $19 \%$ ) of $\mathbf{7 b}$ as orange needles, mp $234^{\circ} \mathrm{C}$; EA: calcd for $\mathrm{C}_{25} \mathrm{H}_{25} \mathrm{BF}_{2} \mathrm{~N}_{2} \mathrm{O}_{2} \mathrm{C}$, 69.14; $\mathrm{H}, 5.80 ; \mathrm{N}, 6.45$; found: C 68.99; $\mathrm{H}, 5.79 ; \mathrm{N}, 6.48 ; \mathrm{UV}-\mathrm{vis}_{\left(\mathrm{CH}_{2} \mathrm{Cl}_{2}\right)}$ : $504 \mathrm{~nm}$ $(\varepsilon=94,300)$; IR $\left(\mathrm{KBr}, \mathrm{cm}^{-1}\right) 2921(\mathrm{CH}), 2851(\mathrm{CH}), 1548,1199,1078$, 976, 838; ${ }^{1} \mathrm{H}$ NMR $\left(\mathrm{CDCl}_{3}\right) \delta 1.11\left(\mathrm{~s}, 6 \mathrm{H}, 2 \times \mathrm{CH}_{3}\right), 2.52(\mathrm{~s}, 6 \mathrm{H}, 2 \times$ $\left.\mathrm{CH}_{3}\right), 3.66\left(\mathrm{~s}, 3 \mathrm{H}, \mathrm{OCH}_{3}\right), 3.98\left(\mathrm{~s}, 3 \mathrm{H}, \mathrm{OCH}_{3}\right), 5.85(\mathrm{~s}, 2 \mathrm{H}), 6.70(\mathrm{~d}$, $J=8 \mathrm{~Hz}, 1 \mathrm{H}), 6.89$ (d, $J=3 \mathrm{~Hz}, 1 \mathrm{H}), 7.07$ (dd, $J=9,3 \mathrm{~Hz}, 1 \mathrm{H}), 7.12$ (d, $J=8 \mathrm{~Hz}, 1 \mathrm{H}), 8.16(\mathrm{~d}, J=9 \mathrm{~Hz}, 1 \mathrm{H}) ;{ }^{13} \mathrm{C}$ NMR $\left(\mathrm{CDCl}_{3}\right) \delta 11.39,12.76$, 
55.70, 55.76, 102.21, 103.79, 117.52, 120.81, 124.09, 124.78, 127.50, $128.85,129.61,134.39,138.51,139.46,153.92,156.16,158.62$; MS (ESI): $\mathrm{M}-1^{+}$found: 433.19 calcd for $\mathrm{C}_{25} \mathrm{H}_{25} \mathrm{BF}_{2} \mathrm{~N}_{2} \mathrm{O}_{2}$ 434.29; HPLC: retention time $=8^{\prime} 16^{\prime \prime}(99.4 \%)$.

4.2.14. 2,6-Diiodo-1,3,5,7-tetramethyl-8-(4,7-dimethoxynaphthalene)-4,4'-difluoroboradiaza indacene (7c). Compound $\mathbf{7 b}$ (0.069 mmol), $\mathrm{I}_{2}(0.138 \mathrm{mmol})$, and $\mathrm{HIO}_{3}(0.138 \mathrm{mmol})$ were made to react as described for compound 1c. The crude product was recovered by filtration then crystallized out of $\mathrm{MeOH}$ affording $30 \mathrm{mg}$ (yield: $63 \%$ ) of $7 \mathrm{c}$ as red needles, $\mathrm{mp}>300{ }^{\circ} \mathrm{C}$; EA: calcd for $\mathrm{C}_{25} \mathrm{H}_{23} \mathrm{BF}_{2} \mathrm{I}_{2} \mathrm{~N}_{2} \mathrm{O}_{2}$ C, 43.77; $\mathrm{H}, 3.38 ; \mathrm{N}, 4.08$; found: $\mathrm{C}, 43.98 ; \mathrm{H}, 3.41$; $\mathrm{N}, 4.12 ; \mathrm{UV}-\mathrm{vis}_{\left(\mathrm{CH}_{2} \mathrm{Cl}_{2}\right)}$ : $538 \mathrm{~nm}(\varepsilon=97,800) ; \mathrm{IR}\left(\mathrm{KBr}, \mathrm{cm}^{-1}\right) 2965$ $(\mathrm{CH}), 2840(\mathrm{CH}), 1532,1189,984,836,524(\mathrm{CI}) ;{ }^{1} \mathrm{H}$ NMR $\left(\mathrm{CDCl}_{3}\right)$ $\delta 1.11\left(\mathrm{~s}, 6 \mathrm{H}, 2 \times \mathrm{CH}_{3}\right), 2.59\left(\mathrm{~s}, 6 \mathrm{H}, 2 \times \mathrm{CH}_{3}\right), 3.64\left(\mathrm{~s}, 3 \mathrm{H}, \mathrm{OCH}_{3}\right), 3.99$ $\left(\mathrm{s}, 3 \mathrm{H}, \mathrm{OCH}_{3}\right), 6.71(\mathrm{~d}, J=8 \mathrm{~Hz}, 1 \mathrm{H}), 6.80(\mathrm{~d}, J=3 \mathrm{~Hz}, 1 \mathrm{H}), 7.09$ (d, $J=3 \mathrm{~Hz}, 1 \mathrm{H}), 7.11(\mathrm{~d}, J=3 \mathrm{~Hz}, 1 \mathrm{H}), 8.18(\mathrm{~d}, J=8 \mathrm{~Hz}, 1 \mathrm{H}) ;{ }^{13} \mathrm{C} \mathrm{NMR}$ $\left(\mathrm{CDCl}_{3}\right) \delta 11.93,12.62,55.68,55.75,86.11,102.60,103.09,117.42$, 120.57, 124.11, 124.62, 127.31, 129.19, 134.62, 138.38, 139.45, 154.31, 155.81, 158.20; MS (ESI): $\mathrm{M}-1^{+}$found: 684.95 calcd for $\mathrm{C}_{25} \mathrm{H}_{23} \mathrm{BF}_{2} \mathrm{I}_{2} \mathrm{~N}_{2} \mathrm{O}_{2}$ 686.08; HPLC: retention time $=17^{\prime} 32^{\prime \prime}$ (99.4\%).

4.2.15. 2,6-Diethyl-1,3,5,7-tetramethyl-8-(2,6-dichlorophenyl)-4,4'difluoroboradiazaindacene (8a). 2,4-Dimethyl-3-ethylpyrrole (3.3 $\mathrm{mmol})$ and 2,6-dichlorobenzaldehyde $(1.5 \mathrm{mmol})$ were made to react as described for compound 1a. The raw material was chromatographed $\left(\mathrm{SiO}_{2}\right.$, petroleum ether $\left./ \mathrm{CH}_{2} \mathrm{Cl}_{2}, 1: 1\right)$ affording $230 \mathrm{mg}$ (yield: $34 \%$ ) of $8 \mathbf{a}$ as brown needles, $\mathrm{mp} 255^{\circ} \mathrm{C}$; EA: calcd for $\mathrm{C}_{23} \mathrm{H}_{25} \mathrm{BCl}_{2} \mathrm{~F}_{2} \mathrm{~N}_{2} \mathrm{C}, 61.50 ; \mathrm{H}, 5.61 ; \mathrm{N}, 6.24$; found: $\mathrm{C} 61.79 ; \mathrm{H}, 5.64 ; \mathrm{N}$, 6.18; UV - vis $\left(\mathrm{CH}_{2} \mathrm{Cl}_{2}\right)$ : $536 \mathrm{~nm}(\varepsilon=72,100)$; IR $\left(\mathrm{KBr}, \mathrm{cm}^{-1}\right) 2960$ (CH), $2924(\mathrm{CH}), 1545,1186,973,788 ;{ }^{1} \mathrm{H} \mathrm{NMR}\left(\mathrm{CDCl}_{3}\right) \delta 0.93(\mathrm{t}, 6 \mathrm{H}$, $\left.J=8 \mathrm{~Hz}, 2 \times \mathrm{CH}_{3}\right), 1.31\left(\mathrm{~s}, 6 \mathrm{H}, 2 \times \mathrm{CH}_{3}\right), 2.25\left(\mathrm{q}, 4 \mathrm{H}, J=8 \mathrm{~Hz}, 2 \times \mathrm{CH}_{2}\right)$, $2.47\left(\mathrm{~s}, 6 \mathrm{H}, 2 \times \mathrm{CH}_{3}\right), 7.29(\mathrm{dd}, J=9,7 \mathrm{~Hz}, 1 \mathrm{H}), 7.32-7.42(\mathrm{~m}, 2 \mathrm{H}) ;{ }^{13} \mathrm{C}$ NMR $\left(\mathrm{CDCl}_{3}\right) \delta 14.95,15.58,16.35,17.42,128.41,129.98,130.12$, 131.64, 132.21, 134.42, 144.26, 157.18; MS (ESI): $M-1^{+}$found: 447.09 calcd for $\mathrm{C}_{23} \mathrm{H}_{25} \mathrm{BCl}_{2} \mathrm{~F}_{2} \mathrm{~N}_{2}$ 449.17; HPLC: retention time $=4^{\prime} 17^{\prime \prime}$ (96.3\%).

4.2.16. 1,3,5,7-Tetramethyl-8-(2,6-dichlorophenyl)-4,4'-difluoroboradiazaindacene (8b). 2,4-Dimethylpyrrole (3.3 $\mathrm{mmol}$ ) and 2,6dichlorobenzaldehyde $(1.5 \mathrm{mmol})$ were made to react as described for compound 1a. The raw material was chromatographed $\left(\mathrm{SiO}_{2}\right.$, petroleum ether $\left.-\mathrm{CH}_{2} \mathrm{Cl}_{2}, 1: 1\right)$ affording $257 \mathrm{mg}$ (yield: $44 \%$ ) of $\mathbf{8 b}$ as brown needles, mp $255{ }^{\circ} \mathrm{C}$; EA: calcd for $\mathrm{C}_{19} \mathrm{H}_{17} \mathrm{BCl}_{2} \mathrm{~F}_{2} \mathrm{~N}_{2} \mathrm{C}$, 58.06; $\mathrm{H}, 4.36 ; \mathrm{N}, 7.13$; found: $\mathrm{C} 57.89 ; \mathrm{H}, 4.38 ; \mathrm{N}, 7.08$; $\mathrm{UV}-\operatorname{vis}_{\left(\mathrm{CH}_{2} \mathrm{Cl}_{2}\right)}: 512 \mathrm{~nm}(\varepsilon=91,100) ; \mathrm{IR}\left(\mathrm{KBr}, \mathrm{cm}^{-1}\right) 2956(\mathrm{CH}), 2924$ $(\mathrm{CH}), 2854(\mathrm{CH}), 1551,1465,1192,976 ;{ }^{1} \mathrm{H} \mathrm{NMR}\left(\mathrm{CDCl}_{3}\right) \delta 1.41(\mathrm{~s}, 6 \mathrm{H}$, $\left.2 \times \mathrm{CH}_{3}\right), 2.50\left(\mathrm{~s}, 6 \mathrm{H}, 2 \times \mathrm{CH}_{3}\right), 5.93(\mathrm{~s}, 2 \mathrm{H}), 7.28(\mathrm{~d}, J=9,7 \mathrm{~Hz}, 1 \mathrm{H})$, 7.35-7.41 (m, 2H); ${ }^{13} \mathrm{C} \mathrm{NMR}\left(\mathrm{CDCl}_{3}\right) \delta 15.69,16.73,127.32,129.09$, 130.58, 131.60, 132.72, 134.48, 144.36, 156.95; MS (ESI): $\mathrm{M}-1^{+}$ found: 391.08 calcd for $\mathrm{C}_{19} \mathrm{H}_{17} \mathrm{BCl}_{2} \mathrm{~F}_{2} \mathrm{~N}_{2}$ 393.07; HPLC: retention time $=4^{\prime} 08^{\prime \prime}(99.6 \%)$.

4.2.17. 2,6-Diiodo-1,3,5,7-tetramethyl-8-(2,6-dichlorophenyl)-4,4'difluoroboradiazaindacene $(\mathbf{8 c})$. Compound $8 \mathbf{b}(0.237 \mathrm{mmol}), \mathrm{I}_{2}$ (0.474 $\mathrm{mmol})$, and $\mathrm{HIO}_{3}(0.474 \mathrm{mmol})$ were made to react as described for compound 1c. The crude product was purified by column chromatography $\left(\mathrm{SiO}_{2}\right.$, petroleum ether $\left./ \mathrm{CH}_{2} \mathrm{Cl}_{2}, 1: 1\right)$ affording $101 \mathrm{mg}$ (yield: $66 \%$ ) of $\mathbf{8 c}$ as red needles mp $210{ }^{\circ} \mathrm{C}$; EA: calcd for $\mathrm{C}_{19} \mathrm{H}_{15} \mathrm{BCl}_{2} \mathrm{~F}_{2} \mathrm{I}_{2} \mathrm{~N}_{2} \mathrm{C}, 35.39 ; \mathrm{H}, 2.34 ; \mathrm{N}, 4.34$; found: $\mathrm{C}, 35.40 ; \mathrm{H}, 2.34$; N, 4.31; UV - vis $\left(\mathrm{CH}_{2} \mathrm{Cl}_{2}\right): 548 \mathrm{~nm}(\varepsilon=76,400) ; \mathrm{IR}\left(\mathrm{KBr}, \mathrm{cm}^{-1}\right) 2965$ (CH), $2942(\mathrm{CH}), 2848(\mathrm{CH}), 1548,1462,1188,970,528(\mathrm{CI}) ;{ }^{1} \mathrm{H}$ NMR $\left(\mathrm{CDCl}_{3}\right) \delta 1.42\left(\mathrm{~s}, 6 \mathrm{H}, 2 \times \mathrm{CH}_{3}\right), 2.58\left(\mathrm{~s}, 6 \mathrm{H}, 2 \times \mathrm{CH}_{3}\right), 7.34(\mathrm{~d}, J=9,7 \mathrm{~Hz}$, $1 \mathrm{H}), 7.37-7.45(\mathrm{~m}, 2 \mathrm{H}) ;{ }^{13} \mathrm{C} \mathrm{NMR}\left(\mathrm{CDCl}_{3}\right) \delta 15.84,16.37,86.06$, $128.98,130.40,131.68,132.95,134.79,144.15,157.94$; MS (ESI):
$\mathrm{M}-1^{+}$found: 642.79 calcd for $\mathrm{C}_{19} \mathrm{H}_{15} \mathrm{BCl}_{2} \mathrm{~F}_{2} \mathrm{I}_{2} \mathrm{~N}_{2}$ 644.86; HPLC: retention time $=5^{\prime} 33^{\prime \prime}$ (92.5\%).

4.2.18. 2,6-Diethyl-1,3,5,7-tetramethyl-8-(2,3,4,5,6-pentafluorophenyl)-4,4'-difluoroboradiaza indacene (9a). 2,4-Dimethyl-3-ethylpyrrole $(3.3 \mathrm{mmol})$ and 2,3,4,5,6-pentafluorobenzaldehyde (1.5 mmol) were made to react as described for compound 1a. The raw material was chromatographed $\left(\mathrm{SiO}_{2}\right.$, petroleum ether- $\mathrm{CH}_{2} \mathrm{Cl}_{2}$ $1: 1)$, the fractions were collected to dryness and the product was treated with cold methanol affording $112 \mathrm{mg}$ (yield: 16\%) of 9a as orange needles, mp $206{ }^{\circ} \mathrm{C}$; EA: calcd for $\mathrm{C}_{23} \mathrm{H}_{22} \mathrm{BF}_{7} \mathrm{~N}_{2} \mathrm{C}, 58.75 ; \mathrm{H}$, 4.72; N, 5.96; found: C, 59.03; $\mathrm{H}, 4.76 ; \mathrm{N}, 6.00$. UV - vis ${ }_{\left(\mathrm{CH}_{2} \mathrm{Cl}_{2}\right)}$ : $534 \mathrm{~nm}(\varepsilon=56,800) ; \mathrm{IR}\left(\mathrm{KBr}, \mathrm{cm}^{-1}\right) 2956(\mathrm{CH}), 2932(\mathrm{CH}), 2850(\mathrm{CH})$, $1548,1468,1180,970 ;{ }^{1} \mathrm{H}$ NMR $\left(\mathrm{CDCl}_{3}\right) \delta 1.02\left(\mathrm{t}, 6 \mathrm{H}, \mathrm{J}=8 \mathrm{~Hz}, 2 \times \mathrm{CH}_{3}\right)$, $1.51\left(\mathrm{~s}, 6 \mathrm{H}, 2 \times \mathrm{CH}_{3}\right), 2.33\left(\mathrm{q}, 4 \mathrm{H}, J=8 \mathrm{~Hz}, 2 \times \mathrm{CH}_{2}\right), 2.54\left(\mathrm{~s}, 6 \mathrm{H}, 2 \times \mathrm{CH}_{3}\right)$; ${ }^{13} \mathrm{C}$ NMR $\left(\mathrm{CDCl}_{3}\right) \delta 14.78,15.32,16.59,17.21,131.25,132.36,134.54$, 140.26, 142.16 (dd, $J=248.9,13.9 \mathrm{~Hz}), 143.39$ (dd, $J=249.9,15.1 \mathrm{~Hz}$ ), 147.52 (dd, $J=241.3,14.9 \mathrm{~Hz}$ ), 155.11; MS (ESI): $\mathrm{M}-1^{+}$found: 469.17 calcd for $\mathrm{C}_{23} \mathrm{H}_{22} \mathrm{BF}_{7} \mathrm{~N}_{2}$ 470.23; HPLC: retention time $=8^{\prime} 41^{\prime \prime}$ (96.0\%).

4.2.19. 1,3,5,7-Tetramethyl-8-(2,3,4,5,6-pentafluorophenyl)-4,4'-difluoroboradiazaindacene (9b). 2,3,4,5,6-Pentafluorobenzaldehyde (1.5 mmol) and 2,4-dimethylpyrrole $(3.3 \mathrm{mmol})$ were made to react as described for compound 1a. The raw material was purified by column chromatography $\left(\mathrm{SiO}_{2}\right.$, petroleum ether $\left./ \mathrm{CH}_{2} \mathrm{Cl}_{2}, 7: 3\right)$, the fractions were collected to dryness and the product precipitated from methanol affording $92 \mathrm{mg}$ (yield: 15\%) of $\mathbf{9 b}$ as green needles, mp $220{ }^{\circ} \mathrm{C}$; EA: calcd for $\mathrm{C}_{19} \mathrm{H}_{14} \mathrm{BF}_{7} \mathrm{~N}_{2} \mathrm{C}, 55.10 ; \mathrm{H}, 3.41 ; \mathrm{N}, 6.76$; found: C, 54.87; $\mathrm{H}, 3.43 ; \mathrm{N}, 6.70 ; \mathrm{UV}-\mathrm{vis}_{\left(\mathrm{CH}_{2} \mathrm{Cl}_{2}\right)}$ : $518 \mathrm{~nm}$ $(\varepsilon=61,500)$; IR $\left(\mathrm{KBr}, \mathrm{cm}^{-1}\right) 2948(\mathrm{CH}), 2836(\mathrm{CH}), 1549,1478,1184$ 961; ${ }^{1} \mathrm{H} \mathrm{NMR}\left(\mathrm{CDCl}_{3}\right) \delta 1.53\left(\mathrm{~s}, 6 \mathrm{H}, 2 \times \mathrm{CH}_{3}\right), 2.49\left(\mathrm{~s}, 6 \mathrm{H}, 2 \times \mathrm{CH}_{3}\right)$, $5.98(\mathrm{~s}, 2 \mathrm{H}) ;{ }^{13} \mathrm{C} \mathrm{NMR}\left(\mathrm{CDCl}_{3}\right) \delta 14.45,16.67,129.13,132.22,135.63$, 139.13, 141.13 (dd, $J=249.6,12.8 \mathrm{~Hz}), 144.13$ (dd, $J=250.0,15.2 \mathrm{~Hz}$ ), 147.63 (dd, $J=243.4,11.9 \mathrm{~Hz}$ ), 155.02; MS (ESI): M-1 ${ }^{+}$found: 413.02 calcd for $\mathrm{C}_{19} \mathrm{H}_{14} \mathrm{BF}_{7} \mathrm{~N}_{2}$ 414.13; HPLC: retention time $=66^{\prime} 48^{\prime \prime}$ (99.5\%).

4.2.20. 2,6-Diiodo-1,3,5,7-tetramethyl-8-(2,3,4,5,6-pentafluorophenyl)-4,4'-difluoroboradiaza indacene (9c). Iodine $(0.170 \mathrm{mmol})$, iodic acid $(0.170 \mathrm{mmol})$, and compound $9 \mathbf{b}(0.085 \mathrm{mmol})$ were made to react as reported for compound 1c. The crude product was purified by column chromatography $\left(\mathrm{SiO}_{2}\right.$, petroleum ether- $\mathrm{CH}_{2} \mathrm{Cl}_{2}, 1: 1$ ) affording $54 \mathrm{mg}$ (yield: $96 \%$ ) of $\mathbf{9 c}$ as red needles, mp $250{ }^{\circ} \mathrm{C}$; EA: calcd for $\mathrm{C}_{19} \mathrm{H}_{12} \mathrm{BF}_{7} \mathrm{I}_{2} \mathrm{~N}_{2} \mathrm{C}, 34.27 ; \mathrm{H}, 1.82 ; \mathrm{N}$, 4.21; found: C, 34.08; $\mathrm{H}, 1.81 ; \mathrm{N}, 4.18 ; \mathrm{UV}-\mathrm{vis}_{\left(\mathrm{CH}_{2} \mathrm{Cl}_{2}\right)}$ : $548 \mathrm{~nm}$ $(\varepsilon=50,500)$; IR $\left(\mathrm{KBr}, \mathrm{cm}^{-1}\right) 2948(\mathrm{CH}), 2836(\mathrm{CH}), 1549,1478,1184$, 961. ${ }^{1} \mathrm{H}$ NMR $\left(\mathrm{CDCl}_{3}\right) \delta 1.56\left(\mathrm{~s}, 6 \mathrm{H}, 2 \times \mathrm{CH}_{3}\right), 2.59\left(\mathrm{~s}, 6 \mathrm{H}, 2 \times \mathrm{CH}_{3}\right) ;{ }^{13} \mathrm{C}$ $\operatorname{NMR}\left(\mathrm{CDCl}_{3}\right) \delta 15.53,16.12,85.01,131.62,135.21,138.11,140.29$ (dd, $J=241.2,11.2 \mathrm{~Hz}$ ), 143.26 (dd, $J=251.2,13.9 \mathrm{~Hz}), 146.32$ (dd, $J=243.2$, $12.8 \mathrm{~Hz}$ ), 154.66; MS (ESI): $\mathrm{M}-1^{-}$found: 664.7 calcd for $\mathrm{C}_{19} \mathrm{H}_{12} \mathrm{BF}_{7} \mathrm{I}_{2} \mathrm{~N}_{2}$ 665.92; HPLC: retention time $=12^{\prime} 08^{\prime \prime}$ (94.9\%).

4.2.21. 2,6-Diethyl-1,3,5,7-tetramethyl-8-(2,3,5,6-tetrafluoro-3-[(4methoxybenzyl)sulfanyl]phenyl)-4,4'-difluoroboradiazaindacene (10a). Compound $9 a(0.128 \mathrm{mmol})$ was dissolved in anhydrous THF $(8 \mathrm{~mL})$, and the solution was stirred under $\mathrm{N}_{2}$ for $5 \mathrm{~min}$. After this period $\mathrm{K}_{2} \mathrm{CO}_{3}$ ( $354 \mathrm{mg}, 2.56 \mathrm{mmol}$ ) was added and the mixture was brought to reflux. A solution of 4-methoxy- $\alpha$-toluenethiol $(1 \mathrm{~mL}$, $2.56 \mathrm{mmol})$, dissolved in anhydrous THF $(9 \mathrm{~mL})$, was then added dropwise over $15 \mathrm{~min}$ and the reaction was kept under reflux for $30 \mathrm{~min}$. After cooling, the mixture was evaporated under vacuum. The crude product was purified by column chromatography $\left(\mathrm{SiO}_{2}\right.$, petroleum ether $/ \mathrm{CH}_{2} \mathrm{Cl}_{2}, 1: 1$ ), precipitated from methanol affording $52 \mathrm{mg}$ (yield 67\%) of 10a as red-purple needles, mp $170{ }^{\circ} \mathrm{C}$; EA: calcd for $\mathrm{C}_{31} \mathrm{H}_{31} \mathrm{BF}_{6} \mathrm{~N}_{2} \mathrm{OS} \mathrm{C}$, 61.60; $\mathrm{H}, 5.17$; N, 4.63; found: C, 62.11; $\mathrm{H}, 5.21$; N, 4.66; UV - vis $\left.\mathrm{CH}_{2} \mathrm{Cl}_{2}\right)$ : $532 \mathrm{~nm}(\varepsilon=60,200)$; IR $(\mathrm{KBr}$, $\mathrm{cm}^{-1}$ ) $2957(\mathrm{CH}), 2924(\mathrm{CH}), 2852(\mathrm{CH}), 1549,1471,1186,969,829$; 


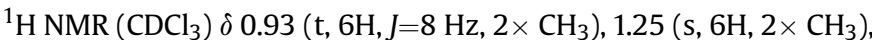
$2.24\left(\mathrm{q}, 4 \mathrm{H}, J=8 \mathrm{~Hz}, 2 \times \mathrm{CH}_{2}\right), 2.45\left(\mathrm{~s}, 6 \mathrm{H}, 2 \times \mathrm{CH}_{3}\right), 3.70\left(\mathrm{~s}, 3 \mathrm{H}, \mathrm{OCH}_{3}\right)$, $4.10\left(\mathrm{~s}, 2 \mathrm{H}, \mathrm{SCH}_{2}\right), 6.98(\mathrm{~d}, J=9 \mathrm{~Hz}, 2 \mathrm{H}), 7.11(\mathrm{~d}, J=9 \mathrm{~Hz}, 2 \mathrm{H}) ;{ }^{13} \mathrm{C} \mathrm{NMR}$ $\left(\mathrm{CDCl}_{3}\right) \delta 13.95,14.72,15.63,16.89,38.06,55.45,114.13,116.12(\mathrm{t}$, $J=21.1 \mathrm{~Hz}), 124.20,127.89,128.35,130.68,131.46,140.56,143.62$ (dd, $J=251.2,15.9 \mathrm{~Hz}$ ), 147.71 (dd, $J=248.0,13.9 \mathrm{~Hz}), 157.23$, 158.86; MS (ESI): $\mathrm{M}-1^{+}$found: 603.15 calcd for $\mathrm{C}_{31} \mathrm{H}_{31} \mathrm{BF}_{6} \mathrm{~N}_{2} \mathrm{OS}$ 604.46; HPLC: retention time $=10^{\prime} 14^{\prime \prime}(99.0 \%)$.

4.2.22. 1,3,5,7-Tetramethyl-8-(2,3,5,6-tetrafluoro-3-[(4-methoxybenzyl)sulfanyl]phenyl)-4,4'-difluoroboradiazaindacene (10b). 4-Methoxy- $\alpha$-toluenethiol ( $3 \mathrm{mmol}$ ) and $\mathbf{9 b}(0.15 \mathrm{mmol})$ were made to react as described for compound 10a. The crude product was purified by column chromatography $\left(\mathrm{SiO}_{2}\right.$, petroleum ether $\left./ \mathrm{CH}_{2} \mathrm{Cl}_{2}, 6: 4\right)$, crystallized out of methanol affording $63 \mathrm{mg}$ (yield 76\%) of 10b as yellow needles, mp $188^{\circ} \mathrm{C}$; EA: calcd for $\mathrm{C}_{27} \mathrm{H}_{23} \mathrm{BF}_{6} \mathrm{~N}_{2} \mathrm{OS} \mathrm{C}, 59.14 ; \mathrm{H}$, 4.23; N, 5.11; found: C, 59.49; $\mathrm{H}, 4.26$; N, 5.12. UV - vis $\left(\mathrm{CH}_{2} \mathrm{Cl}_{2}\right)$ : $516 \mathrm{~nm}(\varepsilon=92,800)$; IR $\left(\mathrm{KBr}, \mathrm{cm}^{-1}\right) 2978(\mathrm{CH}), 2934(\mathrm{CH}), 2850(\mathrm{CH})$, $1552,1465,1178,971 ;{ }^{1} \mathrm{H} \mathrm{NMR}\left(\mathrm{CDCl}_{3}\right) \delta 1.45\left(\mathrm{~s}, 6 \mathrm{H}, 2 \times \mathrm{CH}_{3}\right), 2.56(\mathrm{~s}$, $\left.6 \mathrm{H}, 2 \times \mathrm{CH}_{3}\right), 3.78\left(\mathrm{~s}, 3 \mathrm{H}, \mathrm{OCH}_{3}\right), 4.18\left(\mathrm{~s}, 2 \mathrm{H}, \mathrm{SCH}_{2}\right), 6.03(\mathrm{~s}, 2 \mathrm{H}), 6.76$ $(\mathrm{d}, J=9 \mathrm{~Hz}, 2 \mathrm{H}), 7.18(\mathrm{~d}, J=9 \mathrm{~Hz}, 2 \mathrm{H}) ;{ }^{13} \mathrm{C} \mathrm{NMR}\left(\mathrm{CDCl}_{3}\right) \delta 13.59,14.87$, 38.01, 55.44, 114.09, 115.83 (t, $J=20.4 \mathrm{~Hz}$ ), 122.20, 124.08, 128.23, 130.08, 130.98, 141.84, 143.51 (dd, $J=250.4,16.1 \mathrm{~Hz}$ ), 147.63 (dd, $J=247.9,13.8 \mathrm{~Hz}$ ), 157.62, 159.27; MS (ESI): $\mathrm{M}-1^{+}$found: 547.10 calcd for $\mathrm{C}_{27} \mathrm{H}_{23} \mathrm{BF}_{6} \mathrm{~N}_{2} \mathrm{OS}$ 548.35; HPLC: retention time $=7^{\prime} 50^{\prime \prime}$ (98.3\%).

4.2.23. 2,6-Diiodo-1,3,5,7-tetramethyl-8-(2,3,5,6-tetrafluoro-3-[(4methoxybenzyl)sulfanyl]phenyl)-4,4'-difluoroboradiazaindacene (10c). 4-Methoxy- $\alpha$-toluenethiol $(0.6 \mathrm{mmol})$ and $9 \mathrm{c}(0.03 \mathrm{mmol})$ were made to react as described for compound $\mathbf{1 0 a}$. The crude product was purified by column chromatography $\left(\mathrm{SiO}_{2}\right.$, petroleum ether $-\mathrm{CH}_{2} \mathrm{Cl}_{2}, 1: 1$ ) affording $15 \mathrm{mg}$ (yield $63 \%$ ) of $\mathbf{6}$ as red needles, mp $135^{\circ} \mathrm{C}$; EA: calcd for $\mathrm{C}_{27} \mathrm{H}_{21} \mathrm{BF}_{6} \mathrm{I}_{2} \mathrm{~N}_{2} \mathrm{OS} \mathrm{C}, 40.53 ; \mathrm{H}, 2.65 ; \mathrm{N}, 3.50$; found: C, 40.59; $\mathrm{H}, 2.65 ; \mathrm{N}, 3.51 ; \mathrm{UV}-\mathrm{vis}_{\left(\mathrm{CH}_{2} \mathrm{Cl}_{2}\right)}$ : $546 \mathrm{~nm}$ $(\varepsilon=48,300)$; IR $\left(\mathrm{KBr}, \mathrm{cm}^{-1}\right) 2962(\mathrm{CH}), 2842(\mathrm{CH}), 1559,1480,1161$, 970, $524(\mathrm{CI}) ;{ }^{1} \mathrm{H}$ NMR $\left(\mathrm{CDCl}_{3}\right) \delta 1.48\left(\mathrm{~s}, 6 \mathrm{H}, 2 \times \mathrm{CH}_{3}\right), 2.56(\mathrm{~s}, 6 \mathrm{H}, 2 \times$ $\left.\mathrm{CH}_{3}\right), 3.51\left(\mathrm{~s}, 2 \mathrm{H}, \mathrm{SCH}_{2}\right), 3.72\left(\mathrm{~s}, 3 \mathrm{H}, \mathrm{OCH}_{3}\right), 6.77(\mathrm{~d}, J=9 \mathrm{~Hz}, 2 \mathrm{H}), 7.10$ $(\mathrm{d}, J=9 \mathrm{~Hz}, 2 \mathrm{H}) ;{ }^{13} \mathrm{C} \mathrm{NMR}\left(\mathrm{CDCl}_{3}\right) \delta 13.69,15.26,38.10,55.67,87.11$, 114.26, 115.71 (t, $J=20.1 \mathrm{~Hz}), 124.28,128.01,129.82,130.53,141.11$ 143.36 (dd, $J=249.3,15.6 \mathrm{~Hz}$ ), 147.14 (dd, $J=247.0,12.9 \mathrm{~Hz}$ ), 157.50 , 159.15; MS (ESI): $\mathrm{M}-1^{+}$found: 799.06 calcd for $\mathrm{C}_{27} \mathrm{H}_{21} \mathrm{BF}_{6} \mathrm{I}_{2} \mathrm{~N}_{2} \mathrm{OS}$ 800.14; HPLC: retention time $=15^{\prime} 27^{\prime \prime}(92.3 \%)$.

4.2.24. 2,6-Diethyl-1,3,5,7-tetramethyl-8-(4-pyridyl)-4,4'-difluoroboradiazaindacene (11a). 2,4-Dimethyl-3-ethylpyrrole $(620 \mu \mathrm{L}$, $6 \mathrm{mmol}$ ) and 4-pyridylcarbaldehyde ( $283 \mu \mathrm{L}, 3 \mathrm{mmol}$ ) were made to react as described for compound $\mathbf{1 a}$. The raw material was purified by column chromatography $\left(\mathrm{SiO}_{2}, \mathrm{CH}_{2} \mathrm{Cl}_{2}\right)$, affording $120 \mathrm{mg}$ (yield: $17 \%$ ) of 11a as red needles, mp $196{ }^{\circ} \mathrm{C}$; EA: calcd for $\mathrm{C}_{22} \mathrm{H}_{26} \mathrm{BF}_{2} \mathrm{~N}_{3} \mathrm{C}$, $69.30 ; \mathrm{H}, 6.87 ; \mathrm{N}, 11.02$; found: $\mathrm{C} 69.52 ; \mathrm{H}, 6.91 ; \mathrm{N}, 11.11$; $\mathrm{UV}-\operatorname{vis}_{\left(\mathrm{CH}_{2} \mathrm{Cl}_{2}\right)}: 524 \mathrm{~nm}(\varepsilon=71,400) ; \mathrm{IR}\left(\mathrm{KBr}, \mathrm{cm}^{-1}\right) 3025(\mathrm{CH}), 2978$ (CH), $2922(\mathrm{CH}), 2856(\mathrm{CH}), 1575,1490,1170,981 ;{ }^{1} \mathrm{H}$ NMR $\left(\mathrm{CDCl}_{3}\right)$ $\delta 0.91\left(\mathrm{t}, 6 \mathrm{H}, J=8 \mathrm{~Hz}, 2 \times \mathrm{CH}_{3}\right), 1.23\left(\mathrm{~s}, 6 \mathrm{H}, 2 \times \mathrm{CH}_{3}\right), 2.22(\mathrm{q}, 4 \mathrm{H}$, $\left.J=8 \mathrm{~Hz}, 2 \times \mathrm{CH}_{2}\right), 2.46\left(\mathrm{~s}, 6 \mathrm{H}, 2 \times \mathrm{CH}_{3}\right), 7.23(\mathrm{dd}, J=6,1 \mathrm{~Hz}, 2 \mathrm{H}), 8.69$ (dd, $J=6,1 \mathrm{~Hz}, 2 \mathrm{H}) ;{ }^{13} \mathrm{C}$ NMR $\left(\mathrm{CDCl}_{3}\right) \delta 15.21,15.89,16.45,17.01$, $124.13,130.39,131.52,132.12,138.42,144.26,151.12,156.81$; MS (ESI): $\mathrm{M}-1^{+}$found: 380.15 calcd for $\mathrm{C}_{22} \mathrm{H}_{26} \mathrm{BF}_{2} \mathrm{~N}_{3}$ 381.27; HPLC: retention time $=8^{\prime} 52^{\prime \prime}$ (98.5\%).

4.2.25. 2,6-Diethyl-1,3,5,7-tetramethyl-8-(3-pyridyl)-4,4'-difluoroboradiazaindacene

(12a). 2,4-Dimethyl-3-ethylpyrrole (620 $\mu \mathrm{L}, 6 \mathrm{mmol})$ and 3-pyridylcarbaldehyde (283 $\mu \mathrm{L}, 3 \mathrm{mmol})$ were made to react as described for compound 1a. The raw material was purified by column chromatography $\left(\mathrm{SiO}_{2}, \mathrm{CH}_{2} \mathrm{Cl}_{2}\right)$, affording $120 \mathrm{mg}$ (yield: $17 \%$ ) of $\mathbf{1 2 a}$ as red needles, $\mathrm{mp} 196{ }^{\circ} \mathrm{C}$; EA: calcd for
$\mathrm{C}_{22} \mathrm{H}_{26} \mathrm{BF}_{2} \mathrm{~N}_{3} \mathrm{C}, 69.30 ; \mathrm{H}, 6.87 ; \mathrm{N}, 11.02$; found: C 69.53; H, 6.88; N, 11.05; UV - vis ${\left(\mathrm{CH}_{2} \mathrm{Cl}_{2}\right)}$ : $524 \mathrm{~nm}(\varepsilon=57,000)$; IR $\left(\mathrm{KBr}, \mathrm{cm}^{-1}\right) 3032$ $(\mathrm{CH}), 2963(\mathrm{CH}), 2920(\mathrm{CH}), 2848(\mathrm{CH}), 1577,1486,1161,972 ;{ }^{1} \mathrm{H}$ $\operatorname{NMR}\left(\mathrm{CDCl}_{3}\right) \delta 0.91\left(\mathrm{t}, 6 \mathrm{H}, J=8 \mathrm{~Hz}, 2 \times \mathrm{CH}_{3}\right), 1.21\left(\mathrm{~s}, 6 \mathrm{H}, 2 \times \mathrm{CH}_{3}\right), 2.23$ $\left(\mathrm{q}, 4 \mathrm{H}, J=8 \mathrm{~Hz}, 2 \times \mathrm{CH}_{2}\right), 2.46\left(\mathrm{~s}, 6 \mathrm{H}, 2 \times \mathrm{CH}_{3}\right), 7.48(\mathrm{dd}, J=8,5 \mathrm{~Hz}, 1 \mathrm{H})$, $7.60(\mathrm{dt}, J=8,2 \mathrm{~Hz}, 1 \mathrm{H}), 8.39$ (d, $J=2 \mathrm{~Hz}, 1 \mathrm{H}), 8.71(\mathrm{dd}, J=5,2 \mathrm{~Hz}, 1 \mathrm{H})$; ${ }^{13} \mathrm{C} \mathrm{NMR}\left(\mathrm{CDCl}_{3}\right) \delta 14.76,15.52,16.01,17.26,123.12,131.00,131.65$, $134.15,138.89,145.26,150.96,151.32,156.35$; MS (ESI): $\mathrm{M}-1^{+}$ found: 380.04 calcd for $\mathrm{C}_{22} \mathrm{H}_{26} \mathrm{BF}_{2} \mathrm{~N}_{3}$ 381.27; HPLC: retention time $=8^{\prime} 27^{\prime \prime}(98.0 \%)$.

4.2.26. 1,3,5,7-Tetramethyl-8-(3-pyridyl)-4,4'-difluoroboradiazaindacene (12b). 3-Pyridylcarbaldehyde (3 $\mathrm{mmol}$ ) and 2,4-dimethylpyrrole $(6 \mathrm{mmol})$ were made to react as described for compound 1a. The raw material was purified by column chromatography $\left(\mathrm{SiO}_{2}, \mathrm{CH}_{2} \mathrm{Cl}_{2}\right)$, affording $75 \mathrm{mg}$ (yield: $8 \%$ ) of $\mathbf{1 1 b}$ as green needles, mp $190{ }^{\circ} \mathrm{C}$; EA: calcd for $\mathrm{C}_{18} \mathrm{H}_{18} \mathrm{BF}_{2} \mathrm{~N}_{3} \mathrm{C}, 66.49 ; \mathrm{H}, 5.58$; N, 12.92; found: C, 66.38; $\mathrm{H}, 5.54 ; \mathrm{N}, 13.05 ; \mathrm{UV}-\mathrm{vis}_{\left(\mathrm{CH}_{2} \mathrm{Cl}_{2}\right)}$ : $504 \mathrm{~nm}$ $(\varepsilon=69,800)$; IR $\left(\mathrm{KBr}, \mathrm{cm}^{-1}\right) 3028(\mathrm{CH}), 2969(\mathrm{CH}), 2840(\mathrm{CH}), 1571$, $1488,1167,984 ;{ }^{1} \mathrm{H} \mathrm{NMR}\left(\mathrm{CDCl}_{3}\right) \delta: 1.31\left(\mathrm{~s}, 6 \mathrm{H}, 2 \times \mathrm{CH}_{3}\right), 2.49(\mathrm{~s}, 6 \mathrm{H}$, $\left.2 \times \mathrm{CH}_{3}\right), 5.94(\mathrm{~s}, 2 \mathrm{H}), 7.38(\mathrm{dd}, J=8,5 \mathrm{~Hz}, 1 \mathrm{H}), 7.57(\mathrm{dt}, J=8,2 \mathrm{~Hz}, 1 \mathrm{H})$, $8.50(\mathrm{~d}, J=2 \mathrm{~Hz}, 1 \mathrm{H}), 8.68$ (dd, $J=5,2 \mathrm{~Hz}, 1 \mathrm{H}) ;{ }^{13} \mathrm{C} \mathrm{NMR}\left(\mathrm{CDCl}_{3}\right)$ $\delta$ 14.96, 15.78, 122.85, 129.63, 131.93, 133.68, 137.32, 146.24, 150.21, 150.74, 156.21; MS (ESI): $\mathrm{M}-1^{+}$found: 324.05 calcd for $\mathrm{C}_{18} \mathrm{H}_{18} \mathrm{BF}_{2} \mathrm{~N}_{3} 325.16$; HPLC: retention time $=6^{\prime} 40^{\prime \prime}$ (99.7\%).

4.2.27. 2,6-Diiodo-1,3,5,7-tetramethyl-8-(3-pyridyl)-4,4'-difluoroboradiazaindacene (12c). Iodine $(0.435 \mathrm{mmol})$, iodic acid $(0.435 \mathrm{mmol})$, and compound $\mathbf{1 2 b}(0.217 \mathrm{mmol})$ were made to react as reported for compound 1c. The crude product was purified by column chromatography $\left(\mathrm{SiO}_{2}, \mathrm{CHCl}_{3}\right)$ affording $100 \mathrm{mg}$ (yield: $79 \%$ ) of $12 \mathrm{c}$ as purple needles, $\mathrm{mp}>300{ }^{\circ} \mathrm{C}$; EA: calcd for $\mathrm{C}_{18} \mathrm{H}_{16} \mathrm{BF}_{2} \mathrm{I}_{2} \mathrm{~N}_{3} \mathrm{C}, 37.47 ; \mathrm{H}, 2.80 ; \mathrm{N}, 7.28$ found: $\mathrm{C}, 37.56 ; \mathrm{H}, 2.82 ; \mathrm{N}$, 7.32. UV - vis $\left.\mathrm{CH}_{2} \mathrm{Cl}_{2}\right): 538 \mathrm{~nm}(\varepsilon=67,100) ; \mathrm{IR}\left(\mathrm{KBr}, \mathrm{cm}^{-1}\right) 3021(\mathrm{CH})$, $2962(\mathrm{CH}), 2839(\mathrm{CH}), 1581,1498,1176,978,528 ;{ }^{1} \mathrm{H}$ NMR $\left(\mathrm{CDCl}_{3}\right)$ $\delta 1.56\left(\mathrm{~s}, 6 \mathrm{H}, 2 \times \mathrm{CH}_{3}\right), 2.59\left(\mathrm{~s}, 6 \mathrm{H}, 2 \times \mathrm{CH}_{3}\right), 7.52(\mathrm{dd}, J=8,5 \mathrm{~Hz}, 1 \mathrm{H})$, $7.65(\mathrm{dt}, J=8,2 \mathrm{~Hz}, 1 \mathrm{H}), 8.58(\mathrm{~d}, J=2 \mathrm{~Hz}, 1 \mathrm{H}), 8.67(\mathrm{dd}, J=5,2 \mathrm{~Hz}, 1 \mathrm{H})$; ${ }^{13} \mathrm{C} \mathrm{NMR}\left(\mathrm{CDCl}_{3}\right) \delta 15.63,16.23,87.25,123.95,132.24,133.59,139.14$, 146.52, 151.58, 151.99, 155.21; MS (ESI): $\mathrm{M}-1^{+}$found: 575.21 calcd for $\mathrm{C}_{18} \mathrm{H}_{16} \mathrm{BF}_{2} \mathrm{I}_{2} \mathrm{~N}_{3}$ 576.96; HPLC: retention time $=11^{\prime} 07^{\prime \prime}$ (99.1\%).

\subsection{Fluorescence properties and quantum yield of fluorescence}

Steady-state fluorescence spectroscopic studies were performed on a Jasco FP-750 spectrofluorimeter. The slit width was $2.5 \mathrm{~nm}$ for both excitation and emission. Values of absorbance, necessary for the equation described below, were obtained for the same solutions used in the fluorescence measurements on a Varian Cary 50 Scan instrument. The relative quantum efficiencies of fluorescence of each BODIPY derivative were obtained comparing the emission spectra of the test sample with that of a $0.1 \mathrm{~N} \mathrm{NaOH}$ solution of fluorescein excited at $490 \mathrm{~nm}$, whose quantum efficiency literature value is $0.85 .^{20}$ The quantum efficiencies of fluorescence ( $\Phi_{\text {fluo }}$ ) of the BODIPYs were calculated according to the following equation ( $I_{\text {fluo }}$ is the fluorescence intensity at the specific excitation wavelength, Abs denotes the absorbance at the excitation wavelength)

$$
\begin{aligned}
\Phi_{\text {fluo }}^{\text {sample }}= & \Phi_{\text {fluo }}^{\text {standard }} \times\left(I_{\text {fluo }}^{\text {sample }} / I_{\text {fluo }}^{\text {standard }}\right) \\
& \times\left(\text { Abs }^{\text {standard }} / \text { Abs }^{\text {sample }}\right)
\end{aligned}
$$

\subsection{Comparative singlet-oxygen generation measurements}

A solution of aerated isopropanol, containing $50 \mu \mathrm{M}$ of $1,3-$ diphenylisobenzofuran (DPBF) and $2.5 \mu \mathrm{M}$ of photosensitizers 
was prepared in a glass flask and kept in the dark; $2 \mathrm{~mL}$ of this solution was transferred into a cuvette, placed in the UV-vis instrument and irradiated, at rt, from the open top side with the green LED source for the time required to observe the chemical event (maximum $20 \mathrm{~min}$ ). The DPBF absorbance decrease was measured at $410 \mathrm{~nm}$ and at fixed time intervals, as defined for each experiment. The rate of singlet oxygen production was determined measuring the decrease in the intensity of DPBF absorbance recorded over time. Irradiation of the DPBF-isopropanol solution in the absence of photosensitizer (negative control) and a solution containing $2.5 \mu \mathrm{M}$ of Rose Bengal as a comparative control were also carried out. The relative singlet-oxygen generation rate of each photosensitizer was determined by using Rose Bengal as standard. $^{23}$

\subsection{Photodegradation of the BODIPYs}

A $10 \mu \mathrm{M}$ Phosphate Buffer Solution (PBS) of photosensitizer was prepared in a flask. This solution was irradiated, at rt, for $2 \mathrm{~h}$ with the green LED and a $1 \mathrm{~mL}$ sample was collected every $15 \mathrm{~min}$ and analyzed with the spectrophotometer. The photodegradation rate was determined from the plot of the decrease in the intensity of absorbance versus time. The curves were fitted with an exponential equation from which the half-degradation time could be calculated.

\subsection{Computational methods}

The structures corresponding to the aromatic moieties tethered on the BODIPY meso position were drawn and minimized to their lowest energy conformation using a semi-empirical PM3 method in HYPERCHEM software. With the same software the HOMO energy of the structures was calculated.

\subsection{Cytotoxicity studies}

Human ovarian carcinoma SKOV3 cells were obtained from the American Type Culture Collection (Rockville, MD, USA) and maintained in Dulbecco's modified Eagle medium-F12 (DMEM-F12, Mascia-Brunelli, Milano, Italy) supplemented with $10 \%$ fetal bovine serum, $1 \%$ glutamine, and $0.5 \%$ antibiotic mixture (penicillin, streptomycin, and neomycin), were used for this study. The cell lines were maintained in standard culture conditions at $37{ }^{\circ} \mathrm{C}$ in a humidified $5 \% \mathrm{CO}_{2}$ atmosphere. The antiproliferative effect of the different PS was assessed using the MTT assay. ${ }^{26}$ Briefly, $5 \times 10^{4}$ cells $/ \mathrm{mL}$ were seeded onto 96 -well plates and allowed to grow for $48 \mathrm{~h}$ prior to treatment with different BODIPY concentrations. After $24 \mathrm{~h}$, the BODIPY-containing medium was replaced by PBS, and cells were irradiated under visible light for $2 \mathrm{~h}$ using a green LED (fluence $33 \mathrm{~J} / \mathrm{cm}^{2}$ ). At the end of this time, cells were incubated for $24 \mathrm{~h}$ at $37{ }^{\circ} \mathrm{C}$ in drug-free medium; MTT was then added to each well (final concentration $0.4 \mathrm{mg} / \mathrm{mL}$ ) for $3 \mathrm{~h}$ at $37^{\circ} \mathrm{C}$ and formazan crystals formed through MTT metabolism by viable cells were dissolved in DMSO. Optical densities were measured at $570 \mathrm{~nm}$ using a Universal Microplate Reader EL800 (Bio-Tek Instruments).
Possible intrinsic (i.e., non photodynamic) cytotoxic effects of the BODIPY were assessed on control treated as described above, with BODIPY concentrations tenfold higher than those used for PDT experiments, omitting cell irradiation.

$\mathrm{IC}_{50}$ (i.e., the concentration affecting $50 \%$ of cells) values were obtained by nonlinear regression analysis, using the GraphPad PRISM 3.03 software (GraphPad Software Inc., San Diego CA).

\section{References and notes}

1. Treibs, A.; Kreuzer, F. H. Justus Liebigs Ann. Chem. 1968, 718, 208-223.

2. Ulrich, G.; Ziessel, R.; Harriman, A. Angew Chem., Int. Ed. 2008, 47, 1184-1201.

3. Shah, M.; Thangaraj, K.; Soong, M. L.; Wolford, L.; Boyer, J. H.; Politzer, I. R.; Pavlopoulos, T. G. Heteroat. Chem. 1990, 1, 389-399.

4. (a) Rurack, K.; Kollmannsberger, M.; Daub, J. Angew Chem., Int. Ed. 2001, 40, 385-387; (b) Boens, N.; Leen, V.; Dehaen, W. Chem. Soc. Rev. 2012, 41, $1130-1172$.

5. Golovkova, T. A.; Kozlov, D. V.; Neckers, D. C. J. Org. Chem. 2005, 70, 5545-5549.

6. Monsma, F. J.; Barton, A. C.; Kang, H. C.; Brassard, D. L.; Haugland, R. P.; Sibley, D. R. J. Neurochem. 1989, 52, 1641-1644.

7. Ziessel, R.; Ulrich, G.; Harriman, A. New J. Chem. 2007, 31, 496-501.

8. (a) Ventura, B.; Marconi, G.; Broering, M.; Kruger, R.; Flamigni, L. New J. Chem. 2009, 33, 428-438; (b) Guzow, K.; Kornowska, K.; Wiczk, W. Tetrahedron Lett. 2009, 50, 2908-2910; (c) Fron, E.; Coutino-Gonzalez, E.; Pandey, L.; Sliwa, M.; Van der Auweraer, M.; De Schryver, F. C.; Thomas, J.; Dong, Z.; Leen, V.; Smet, M.; Dehaen, W.; Vosch, T. New J. Chem. 2009, 33, 1490-1496.

9. (a) Li, L.; Nguyen, B.; Burgess, K. Bioorg. Med. Chem. Lett. 2008, 18, 3112-3116; (b) Sobenina, L. N.; Vasil'tsov, A. M.; Petrova, O. V.; Petrushenko, K. B.; Ushakov I. A.; Clavier, G.; Meallet-Renault, R.; Mikhaleva, A. I.; Trofimov, B. A. Org. Lett. 2011, 13, 2524-2527.

10. (a) Kee, H. L.; Kirmaier, C.; Yu, L.; Thamyongkit, P.; Youngblood, W. S.; Calder, M.; Ramos, L.; Noll, B. C.; Bocian, D. F.; Scheidt, W. R.; Birge, R. R.; Lindsey, J. S.; Holten, D. J. Phys. Chem. B 2005, 109, 20433-20443; (b) Lager, E.; Liu, J.; AguilarAguilar, A.; Tang, B. Z.; Pena-Cabrera, E. J. Org. Chem. 2009, 74, 2053-2058.

11. (a) Kolemen, S.; Bozdemir, O. A.; Cakmak, Y.; Barin, G.; Erten-Ela, S.; Marszalek, M.; Yum, J.; Zakeeruddin, S. M.; Nazeeruddin, M. K.; Gratzel, M.; Akkaya, E. U. Chem. Sci. 2011, 2, 949-954; (b) Cakmak, Y.; Kolemen, S.; Duman, S.; Dede, Y.; Dolen, Y.; Kilic, B.; Kostereli, Z.; Yildirim, L. T.; Dogan, A. L.; Guc, D.; Akkaya, E. U. Angew. Chem., Int. Ed. 2011, 50, 1-6.

12. (a) Yogo, T.; Urano, Y.; Ishitsuka, Y.; Maniwa, F.; Nagano, T. J. Am. Chem. Soc. 2005, 127, 12162-12163; (b) Banfi, S.; Caruso, E.; Zaza, S.; Mancini, M.; Gariboldi, M.; Monti, E. J. Photochem. Photobiol., B 2012, 114, 52-60.

13. Dougherty, T. J.; Gomer, C. J.; Henderson, B. W.; Jori, G.; Kessel, D.; Korbelik, M.; Moan, J.; Perez, O. J. Natl. Cancer Inst. 1998, 90, 889-905.

14. (a) De Rosa, M. C.; Crutchley, R. J. Coord. Chem. Rev. 2002, 233-234, 351-371; (b) Sharman, W. M.; Allen, C. M.; van Lier, J. E. Methods in Enzymol. 2000, 319, 376-400.

15. Turro, N. J. Modern Molecular Photochemistry; University Science Books: Sausalito, CA, 1991191-195.

16. Yuster, P.; Weissman, S. I. J. Chem. Phys. 1949, 17, 1182-1188.

17. (a) Koziar, J. C.; Cowan, D. O. Acc. Chem. Res. 1978, 334-341; (b) McGlynn, S. P.; Reynolds, M. J.; Daigre, G. W.; Christodoyleas, N. D. J. Phys. Chem. 1962, 66, 2499-2505.

18. (a) Akkaya, E. U.; Dost, Z.; Atilgan, S. Tetrahedron 2006, 62, 8484-8488; (b) Liu, J. Y.; Yeund, H. S.; Xu, W.; Li, X.; Ng, D. K. P. Org. Lett. 2008, 10, 5421-5424.

19. Lim, S. H.; Thivierge, C.; Nowak-Sliwinska, P.; Han, J.; Van den Bergh, H.; Wagnières, G.; Burgess, K.; Lee, H. B. J. Med. Chem. 2010, 53 (7), 2865-2874.

20. Parker, C. A.; Rees, W. T. Analyst 1960, 85, 587-600.

21. Rurack, K.; Kollmannsberger, M.; Daub, J. New J. Chem. 2001, 25, 289-292.

22. (a) Yamada, K.; Toyota, T.; Takakura, K.; Ishimura, M.; Sugawara, T. New J. Chem. 2001, 25, 667-669; (b) Prieto, J. B.; Arbeloa, F. L.; Martinez, V. M.; Lopez, T. A.; Amat-Guerri, F.; Liras, M.; Arbeloa, I. L. Chem. Phys. Lett. 2004, 385, 29-35.

23. Kochevar, I. E.; Redmond, R. W. Methods Enzymol. 2000, 319, 20-28.

24. Lissi, E. A.; Encinas, M. V.; Lemp, E.; Rubio, M. A. Chem. Rev. 1993, 93, 699-723.

25. Caruso, E.; Banfi, S.; Barbieri, P.; Leva, B.; Orlandi, V. T. J. Photochem. Photobiol., B 2012, 114, 44-51.

26. Alley, M. C.; Scudiero, D. A.; Monks, A.; Hursey, M. L.; Czerwinski, M. J.; Fine, D. L.; Abbott, B. J.; Mayo, J. G.; Shoemaker, R. H.; Boyd, M. R. Cancer Res. 1988, 48 , 589-601. 